\title{
MODELLING LONG-RUN TRENDS AND CYCLES \\ IN FINANCIAL TIME SERIES DATA
}

\author{
Guglielmo Maria Caporale \\ Brunel University, London, United Kingdom \\ Juncal Cuñado \\ University of Navarra, Pamplona, Spain
}

Luis A. Gil-Alana

University of Navarra and

Navarra Center for International Development, ICS, Pamplona, Spain

\author{
Revised, September 2012
}

\begin{abstract}
This paper proposes a general time series framework to capture the long-run behaviour of financial series. The suggested approach includes linear and segmented time trends, and stationary and nonstationary processes based on integer and/or fractional degrees of differentiation. Moreover, the spectrum is allowed to contain more than a single pole or singularity, occurring at both zero but non-zero (cyclical) frequencies. This framework is used to analyse five annual time series with a long span, namely dividends, earnings, interest rates, stock prices and long-term government bond yields. The results based on several likelihood criteria indicate that the five series exhibit fractional integration with one or two poles in the spectrum, and are quite stable over the sample period examined.
\end{abstract}

JEL Classification: C22, G1

Keywords: Fractional Integration; Financial Time Series Data; Trends; Cycles

Corresponding author: Professor Guglielmo Maria Caporale, Centre for Empirical Finance, Brunel University, West London, UB8 3PH, UK. Tel.: +44 (0)1895 266713. Fax: +44 (0)1895 269770. Email: Guglielmo-Maria.Caporale@brunel.ac.uk

The third-named author gratefully acknowledges financial support from the Ministerio de Ciencia y Tecnologia (ECO2012-2014, n.28196 ECON Y FINANZAS, Spain) and from a Jeronimo de Ayanz project of the Government of Navarra. Comments from an anonymous referee are gratefully acknowledged. 


\section{Introduction}

The statistical modelling of financial time series data such as asset prices plays an important role in portfolio management. Despite the extensive theoretical and empirical literature of the last thirty years, there is still no consensus on what might be the most adequate model specification for many financial series. For instance, whether asset returns of asset prices are predictable or not is still controversial. While the efficiency market hypothesis suggests that they should follow a random walk (see Fama, 1970; Summers, 1986), other authors have found evidence of mean reversion in their behaviour (see, e.g., Poterba and Summers, 1988 and Fama and French, 1988). The standard econometric approach to settle this issue empirically relies on establishing the (integer) order of integration of the series by carrying out unit root tests. More recently, however, the possibility of fractional orders of integration with a slow rate of decay has also been taken into account. Long-memory specifications based on fractional differentiation have been used for financial data by Crato (1994), Cheung and Lai (1995), Barkoulas and Baum (1996), Barkoulas, Baum, and Travlos (2000), Sadique and Silvapulle (2001), Henry (2002), Tolvi (2003) and Gil-Alana (2006) among others. Also using a fractional model, Caporale and Gil-Alana (2002) find that there is no permanent component in US stock market returns, since the series examined is close to being $\mathrm{I}(0)$. Caporale and Gil-Alana (2007) decompose the stochastic process followed by US stock prices into a long-run component described by the fractional differencing parameter (d) and a short-run (ARMA) structure. Empirical support for non-linear asset pricing models (such as the one by Dittmar, 2002) has also been found (see, inter alia, Hossein and Sonnie, 2008).

The present paper takes into account these various strands of the literature on modelling asset prices and other financial series and proposes a general time series framework to capture the long-run behaviour of financial data. This approach, not 
previously used in this context, includes linear and non-linear (segmented) time trends, and stationary and nonstationary processes based on integer and/or fractional degrees of differentiation. Moreover, the spectrum is allowed to contain more than a single pole or singularity, occurring at both zero and non-zero (cyclical) frequencies. We examine five annual time series with a long span, namely dividends, earnings, interest rates, stock prices and long-term government bond yields, obtainable from Robert Shiller's homepage (http://www.econ.yale.edu/ shiller/). We are able to show that the selected specifications (with linear and segmented trends, fractional integration and cyclical fractional integration) perform better than alternative models used in the literature to analyse these data.

A rationale for the use of this type of models is that they are sufficiently general to include as particular cases several theories that have been put forward in the financial literature in recent years, such as the Efficiency Market Hypothesis (Fama, 1970), mean reversion in stock market prices (Poterba and Summers, 1988), Fractal Market Analysis (Peters, 1994) and the connection between business cycles and financial data (Bernanke et al., 1999; Stock and Watson, 2003, 2005; Farmer, 2012).

With respect to business cycles, it has been commonly argued that they are of a stationary nature and little attention has been paid to them in the context of financial data. ${ }^{1}$ However, it has become increasingly clear that the cyclical component of economic and financial series is also very important. This has been widely documented, especially in the case of business cycles, for which non-linear (Beaudry and Koop, 1993, Pesaran and Potter, 1997) or fractionally ARIMA (ARFIMA) models (see Candelon and Gil-Alana, 2004) have been proposed. Furthermore, from a pure time series viewpoint, it has been argued that cycles should be modelled as an additional component to the trend and the seasonal structure of the series (see Harvey, 1985, Gray et al., 1989). The available evidence

\footnotetext{
${ }^{1}$ Note that the definition of business cycle adopted in this paper is based on deviations from the long-term trend. This is the reason for its stationarity in contrast to the definition provided by the Business Cycle Dating Committee of the NBER considering the level of the series.
} 
suggests that the periodicity of the series ranges between five and ten years, in most cases a periodicity of about six years being estimated (see, e.g., Baxter and King, 1999; Canova, 1998; King and Rebelo, 1999). Our results, based on methods that determine endogenously the length of the cycles also suggest approximately six years of duration.

Given this evidence on the key role played by the cyclical component, we consider both long-run trends and cycles and model the two components either as a long-memory, or as a short-memory process, or even as a combination of the two. Moreover, we allow for segmented trends. Therefore, this paper makes a methodological contribution by incorporating segmented trends in a general framework using long- and short-memory processes at zero and non-zero frequencies. The model presented here has not been previously employed in the financial time series literature and its generality allows to consider other more standard models as particular cases of interest. The present study also contributes to the literature by applying this procedure to several financial time series that have been widely examined in the literature using other, more classical methods.

The structure of the paper is as follows. Section 2 describes the model and the statistical approach employed in the paper. Section 3 presents the empirical analysis, considering first the case with linear trends and then allowing for a break in the data. This section also includes some forecasting performance analysis, whilst Section 4 offers some concluding comments.

\section{The model}

Let us assume that $\left\{\mathrm{y}_{\mathrm{t}}, \mathrm{t}=1,2, . ., \mathrm{T}\right\}$ is the time series we observe. We consider the following model:

$$
\begin{gathered}
y_{t}=f(t)+x_{t}, \quad t=1,2, \ldots, \\
(1-L)^{d_{1}}\left(1-2 \cos w_{r} L+L^{2}\right)^{d_{2}} x_{t}=u_{t},
\end{gathered}
$$




$$
\phi_{p}(L) u_{t}=\theta_{q}(L) \varepsilon_{t}
$$

where $\mathrm{f}$ is a function of time that may be of a linear/non-linear nature $;^{2} \mathrm{~L}$ is the lag operator (i.e., $\left.L^{s} x_{t}=x_{t-s}\right) ; d_{1}$ is the order of integration corresponding to the long-run or zero frequency; $\mathrm{w}_{\mathrm{r}}=2 \pi / \mathrm{r}$, with $\mathrm{r}$ representing the number of periods per cycle; $\mathrm{d}_{2}$ is the order of integration with respect to the non-zero (cyclical) frequency, and $\mathrm{u}_{\mathrm{t}}$ is assumed to be an $\mathrm{I}(0)$ process $^{3}$, that may follow a stationary $\operatorname{ARMA}(\mathrm{p}, \mathrm{q})$ process, where $\phi_{p}(L)$ $=\left(1-\phi_{1} L-\ldots-\phi_{p} L^{p}\right)$ and $\theta_{q}(L)=\left(1+\theta_{1} L+\ldots+\theta_{q} L^{q}\right)$ are polynomials of orders $\mathrm{p}$ and q with all the roots outside the unit circle, and corresponding to the autoregressive (AR) and moving average (MA) components respectively. Note that $d_{1}$ and $d_{2}$ are allowed to be any real values and thus we do not restrict ourselves to integer degrees of differentiation.

The set-up described in (1) - (3) is fairly general, including the standard ARMA model (with or without trends), if $\mathrm{d}_{1}=\mathrm{d}_{2}=0$; the ARIMA case, if $\mathrm{d}_{1}$ is integer and $\mathrm{d}_{2}=0$; the standard ARFIMA specification, if $\mathrm{d}_{1}$ is fractional and $\mathrm{d}_{2}=0$; unit root cycles (Bierens, 2001) if $\mathrm{d}_{1}=0$ and $\mathrm{d}_{2}=1$, along with other more complex representations.

We now focus on equation (2), and first assume that $d_{2}=0$. Then, for $d_{1} \neq 0$, the spectral density function of $x_{t}$ is given by:

$$
f(\lambda)=\frac{\sigma^{2}}{2 \pi}\left|\frac{\theta\left(e^{i \lambda}\right)}{\phi\left(e^{i \lambda}\right)}\right|^{2}\left|1-e^{i \lambda}\right|^{-2 d_{1}}
$$

and it contains a pole or singularity at the long-run or zero frequency, i.e.,

$$
f(\lambda) \rightarrow \infty, \quad \text { as } \quad \lambda \rightarrow 0^{+}
$$

\footnotetext{
2 In the context of a linear deterministic trend, $f(t)=\alpha+\beta t$. Examples of non-linear trends are the Chebychev polynomials (see Hamming, 1973; Bierens, 1997) or segmented trends with dummies as those employed in this paper.

${ }^{3}$ For the purpose of the present paper, an $\mathrm{I}(0)$ process is defined as a covariance stationary process with spectral density function that is positive and finite at any frequency in the interval $[0, \pi)$.
} 
Further, note that the polynomial $(1-L)^{d_{1}}$ can be expressed in terms of its Binomial expansion, such that, for all real $\mathrm{d}_{1}$,

$$
(1-L)^{d_{1}}=\sum_{j=0}^{\infty}\left(\begin{array}{l}
d_{1} \\
j
\end{array}\right)(-1)^{j} L^{j}=1-d_{1} L+\frac{d_{1}\left(d_{1}-1\right)}{2} L^{2}-\ldots,
$$

implying that the higher is the value of $d_{1}$, the higher is the degree of association between observations distant in time. Thus, the parameter $d_{1}$ plays a crucial role in determining the degree of persistence of the series. Although the time series literature for very long only considered the cases of integer values of $d_{1}$ (stationarity if $d_{1}=0$, and nonstationarity with $d_{1}=1$ ), more recently fractional values of $d_{1}$ have been widely employed when modelling macroeconomic and financial data. ${ }^{4}$ Assume now that $d_{1}=0$ in (2). Then, if $d_{2} \neq 0$, the process $\mathrm{x}_{\mathrm{t}}$ has a spectral density function given by:

$$
f(\lambda)=\frac{\sigma^{2}}{2 \pi}\left|\frac{\theta\left(e^{i \lambda}\right)}{\phi\left(e^{i \lambda}\right)}\right|^{2}\left|2\left(\cos (\lambda)-\cos \left(w_{r}\right)\right)\right|^{-2 d_{2}}
$$

and is characterised by having a pole at a non-zero frequency, i.e.,

$$
f(\lambda) \rightarrow \infty, \quad \text { as } \quad \lambda \rightarrow \lambda^{*}, \quad \lambda^{*} \in(0, \pi)
$$

Moreover, the polynomial $\left(1-2 \cos w_{r} L+L^{2}\right)^{d_{2}}$ can be expressed as a Gegenbauer polynomial, such that, defining $\mu=\cos w_{r}$, for all $d_{2} \neq 0$,

$$
\left(1-2 \mu L+L^{2}\right)^{-d_{2}}=\sum_{j=0}^{\infty} C_{j, d_{2}}(\mu) L^{j}
$$

where $C_{j, d_{2}}(\mu)$ are orthogonal Gegenbauer polynomial coefficients recursively defined as:

\footnotetext{
${ }^{4}$ Empirical applications using fractional values of $\mathrm{d}_{1}$ include among others Diebold and Rudebusch (1989), Sowell (1992), Baillie (1996) and Gil-Alana and Robinson (1997).
} 


$$
\begin{gathered}
C_{0, d_{2}}(\mu)=1, \\
C_{1, d_{2}}(\mu)=2 \mu d_{2}, \\
C_{j, d_{2}}(\mu)=2 \mu\left(\frac{d_{2}-1}{j}+1\right) C_{j-1, d_{2}}(\mu)-\left(2 \frac{d_{2}-1}{j}+1\right) C_{j-2, d_{2}}(\mu), \quad j=2,3, \ldots .
\end{gathered}
$$

(see, inter alia, Magnus et al., 1966, or Rainville, 1960, for further details on Gegenbauer polynomials). Gray et al. $(1989,1994)$ showed that this process is stationary if $d_{2}<0.5$ for $\left|\mu=\cos w_{r}\right|<1$ and if $d_{2}<0.25$ for $|\mu|=1$. If $\mathrm{d}_{2}=1$, the process is said to contain a unit root cycle (Ahtola and Tiao, 1987; Bierens, 2001); other applications using fractional values of $\mathrm{d}_{2}$ can be found in Gil-Alana (2001), Ahn, Knopova and Leonenko (2004) and Soares and Souza (2006). ${ }^{5}$

In the empirical analysis carried out in the following section we use a method developed by Robinson (1994) that enables us to test a model such as the one given by equations (1) - (3). It is a very general testing procedure based on the Lagrange Multiplier (LM) principle that uses the Whittle function in the frequency domain. It can be used to test the null hypothesis:

$$
H_{o}: d \equiv\left(d_{1}, d_{2}\right)^{T}=\left(d_{1 o}, d_{2 o}\right)^{T} \equiv d_{o}
$$

in (1) - (3) where $d_{10}$ and $d_{20}$ may be real values, thus encompassing stationary and nonstationary hypotheses. The specific form of the test statistic (denoted by $\hat{R}$ ) is presented in the appendix. Under very general regularity conditions, Robinson (1994) showed that for this particular version of his tests,

$$
\hat{R} \rightarrow_{d} \chi_{2}^{2}, \quad \text { as } \quad T \rightarrow \infty
$$

\footnotetext{
${ }^{5}$ Models with multiple cyclical structures ( $k$-factor Gegenbauer processes) with multiple poles in the spectrum have been examined, among others, by Ferrara and Guegan (2001), Sadek and Khotanzad (2004) and Gil-Alana (2007a).
} 
where " $\rightarrow \mathrm{d}$ " stands for convergence in distribution. Thus, unlike in other procedures, we are in a classical large-sample testing situation. A test of (8) will reject $\mathrm{H}_{\mathrm{o}}$ against the alternative $\mathrm{H}_{\mathrm{a}}: \mathrm{d} \neq \mathrm{d}_{\mathrm{o}}$ if $\hat{R}>\chi_{2, \alpha}^{2}$, where Prob $\left(\chi_{2}^{2}>\chi_{2, \alpha}^{2}\right)=\alpha$. Furthermore the test is efficient in the Pitman sense against local departures from the null, that is, if the test is implemented against local departures of the form: $\mathrm{H}_{\mathrm{a}}: \mathrm{d}=\mathrm{d}_{\mathrm{o}}+\delta \mathrm{T}^{-1 / 2}$, for $\delta \neq 0$, the limit distribution is a $\chi_{2}^{2}(v)$, with a non-centrality parameter $\mathrm{v}$ that is optimal under Gaussianity of $u_{t}$.

There exist other procedures for estimating and testing the fractionally differenced parameters, some of them also based on the likelihood function. As in other standard largesample testing situations, Wald and LR test statistics against fractional alternatives will have the same null and local limit theory as the LM tests of Robinson (1994). For example, for the zero frequency Lobato and Velasco (2007) proposed a Wald test that requires a consistent estimate of $\mathrm{d}_{1}$. Ooms (1997) proposed tests based on seasonal fractional models: they are also Wald tests requiring consistent estimates of the fractional differencing parameters. He used a modified periodogram regression estimation procedure due to Hassler (1994). Also, Hosoya (1997) established the limit theory for long-memory processes with the singularities not restricted at the zero frequency, and proposed a set of quasi log-likelihood statistics to be applied to raw time series. ${ }^{6}$ Unlike these previous methods, the tests of Robinson (1994) do not require estimation of the long-memory parameters since the differenced series have short memory under the null. Thus, his LM method seems computationally more attractive. ${ }^{7}$

\footnotetext{
${ }^{6}$ Models with a pole in the spectrum at the non-zero frequency were also considered, among others, by Giraitis, Hidalgo and Robinson (2001), Hidalgo and Soulier (2004) and Hidalgo (2005). These authors assume that the pole in the spectrum is unknown and suggest various parametric and semiparametric methods to estimate the fractional parameter $\left(\mathrm{d}_{2}\right)$, along with the frequency of the pole. See also Arteche and Robinson (2000) and Arteche (2002) for semiparametric estimates of $d_{2}$.

7 See also Tanaka (1999) and Hassler, Rodrigues and Rubia (2009) for time domain representations of Robinson's (1994) tests.
} 


\section{Empirical Analysis}

The data analysed in this paper have been obtained from Robert Shiller's homepage (http://www.econ.yale.edu/ shiller/). They are described in chapter 26 of Shiller's (1989) book on "Market Volatility", where further details can be found, and are constantly updated and revised. Specifically, they are the following series: dividends (an index), earnings (also an index), one-year interest rate (this series is the result of converting the January and July rates into an annual yield), long-term government bond yield (this is the yield on the 10year Treasury bonds after 1953) and the S\&P composite stock price index. The sample period goes from 1871 to 2010 for the first two series and to 2011 for the remaining three.

\section{[INSERT FIGURE 1 ABOUT HERE]}

Figure 1 contains plots of the five series. As can be seen, dividends, earnings and stock prices appear to be quite stable for about a century, then increase sharply in the last few decades of the sample, with an irregular pattern in the last few years coinciding with the recent financial crisis. Interest rates and government bond yields fluctuate a lot more throughout the sample, but also seem to increase towards the end of the sample, before a significant fall.

In the following two subsections, we examine first a model with linear trends, and then one with a single break. ${ }^{8}$ In both cases we allow for long-range dependence at both zero and non-zero (cyclical) frequencies.

\footnotetext{
${ }^{8}$ Allowing for more than one break would result in relatively small subsamples, invalidating the analysis based on long-range dependence.
} 


\subsection{The case of linear trends}

First we consider the case of linear structures, and assume that the series exhibit a linear time trend in a model containing two stochastic structures, one for the long-term behaviour and the other for the cyclical component. We allow both components to display longmemory behaviour, and test the null hypothesis in (8), in the following model,

$$
\begin{gathered}
y_{t}=\alpha+\beta t+x_{t}, \\
(1-L)^{d_{1}}\left(1-2 \cos w_{r} L+L^{2}\right)^{d_{2}} x_{t}=u_{t},
\end{gathered}
$$

under the assumption that the disturbance term $u_{t}$ is white noise, $\operatorname{AR}(1)$ and $\operatorname{AR}(2)$ respectively. ${ }^{9}$ Higher AR orders and other MA (ARMA) structures were also employed, with similar results. In all cases, we test $H_{o}$ for $\left(d_{10}, d_{20}\right)$-values from -1 to 3 with 0.01 increments, and $\mathrm{r}=2,3, \ldots, \mathrm{T} / 2,{ }^{10}$ choosing as estimates of $\mathrm{d}_{1}$ and $\mathrm{d}_{2}$ the values of $\mathrm{d}_{1 \mathrm{o}}$ and $\mathrm{d}_{2 \mathrm{o}}$ that produce the lowest statistics. These values should be an approximation to the maximum likelihood estimates, noting that Robinson's (1994) method is based on the Whittle function, which is an approximation to the likelihood function. Several Monte Carlo experiments based on this approach were conducted by Caporale and Gil-Alana (2006), and Gil-Alana (2007b). It is shown in these papers that this method correctly determines the orders of integration at the two frequencies for samples of similar size to those employed in this article. Given that some of the coefficients in (10) were not statistically significant, we also carried out the computations in a model with only an intercept (i.e. $\beta=0$ a priori) and with no regressors at all $(\alpha=\beta=0$ a priori). The results for the five series are displayed in Table 1.

\footnotetext{
${ }^{9}$ The inclusion of a time trend might appear unrealistic in the context of financial data. Note, however, that in the context of fractional (or integer) differentiation, the time trend disappears in the long run. Thus, for example, in the model, $\mathrm{y}_{\mathrm{t}}=\alpha+\beta \mathrm{t}+\mathrm{x}_{\mathrm{t}},(1-\mathrm{L})^{\mathrm{d}} \mathrm{x}_{\mathrm{t}}=\mathrm{u}_{\mathrm{t}}$, with white noise $\mathrm{u}_{\mathrm{t}}$, if $\mathrm{d}=1$, the model becomes, for $\mathrm{t}$ > 1 , a random walk with a drift.

${ }^{10}$ Note that in case of $\mathrm{r}=1$, the polynomial $\left(1-2 \cos w_{r} L+L^{2}\right)^{d_{2}}$ becomes $(1-L)^{2 d_{2}}$, implying the existence of a pole at the long run or zero frequency.
} 
Noting also that in some cases the order of integration for the cyclical part $\left(\mathrm{d}_{2}\right)$ was not statistically significantly different from zero, we additionally perform the analysis with a single fractional differencing parameter, i.e., employing

$$
(1-L)^{d_{1}} x_{t}=u_{t}
$$

rather than (11). The results for this case are displayed in Table 2. We describe first of all the results for the case of the two fractional structures.

\section{[INSERT TABLE 1 ABOUT HERE]}

The first remark to make is that the parameter $r$ (indicating the number of time periods per cycle) lies between 2 and 15 in all cases, being around 8 in the majority of cases. This is consistent with the empirical findings in the business cycle literature (Canova, 1998; Burnside, 1998; King and Rebelo, 1999; etc.) according to which economic cycles have a periodicity between five and ten years. It is also noteworthy that the order of integration at the long-run or zero frequency (i.e., $d_{1}$ ) is substantially higher than its corresponding value at the cyclical frequency $\left(\mathrm{d}_{2}\right)$ in practically all cases. For earnings, interest rates and stock prices the unit root null cannot be rejected at the long-run frequency $\left(d_{1}=1\right)$, while $d_{2}$ is found to be strictly below 1 in all cases. We report in Table 1 in bold the cases where the null hypothesis of uncorrelated errors cannot be rejected at conventional statistical levels. ${ }^{11}$ There are two such cases for dividends, a single one for earnings, six for interest rates, five for government bond yields, and four for the stock price index. Among these selected models we choose the best specification on the basis of LR tests and other likelihood criteria, namely the AIC and the SIC. Note, however, that these might not necessarily be the best criteria in applications involving fractional differences, as

\footnotetext{
${ }^{11}$ We use here the Box-Pierce and Ljung-Box-Pierce statistics (Box and Pierce, 1970; Ljung and Box, 1978).
} 
they focus on the short-term forecasting ability of the fitted model and may not give sufficient attention to the long-run properties of the fractional models (see, e.g. Hosking, 1981, 1984). The selected model for each series is the following: for dividends,

$$
\mathrm{y}_{\mathrm{t}}=-77.061+\mathrm{x}_{\mathrm{t}} ; \quad(1-\mathrm{L})^{1.35}\left(1-2 \cos \mathrm{w}_{10} \mathrm{~L}+\mathrm{L}^{2}\right)^{0.17} \mathrm{x}_{\mathrm{t}}=\varepsilon_{\mathrm{t}} .
$$

For earnings,

$$
\begin{gathered}
y_{t}=-94.241+x_{t} ; \quad(1-L)^{1.08}\left(1-2 \cos w_{7} L+L^{2}\right)^{0.35} x_{t}=u_{t} \\
u_{t}=0.953 u_{t-1}-0.695 u_{t-2}+\varepsilon_{t} .
\end{gathered}
$$

For interest rates,

$$
(1-\mathrm{L})^{0.77}\left(1-2 \cos \mathrm{w}_{8} \mathrm{~L}+\mathrm{L}^{2}\right)^{0.23} \mathrm{x}_{\mathrm{t}}=\mathrm{u}_{\mathrm{t}} ; \quad \mathrm{u}_{\mathrm{t}}=0.082 \mathrm{u}_{\mathrm{t}-1}-0.678 \mathrm{u}_{\mathrm{t}-2}+\varepsilon_{\mathrm{t}} \cdot(1 \mathrm{C})
$$

For government bond yields,

$$
\begin{gathered}
\mathrm{y}_{\mathrm{t}}=-117.56+\mathrm{x}_{\mathrm{t}} ; \quad(1-\mathrm{L})^{1.08}\left(1-2 \cos \mathrm{w}_{8} \mathrm{~L}+\mathrm{L}^{2}\right)^{0.24} \mathrm{x}_{\mathrm{t}}=\mathrm{u}_{\mathrm{t}}, \\
\mathrm{u}_{\mathrm{t}}=0.133 \mathrm{u}_{\mathrm{t}-1}+\varepsilon_{\mathrm{t}} \cdot 1
\end{gathered}
$$

and finally, for stock prices,

$$
\begin{gathered}
\mathrm{y}_{\mathrm{t}}=-1506.6+\mathrm{x}_{\mathrm{t}} ; \quad(1-\mathrm{L})^{1.11}\left(1-2 \cos \mathrm{w}_{8} \mathrm{~L}+\mathrm{L}^{2}\right)^{0.50} \mathrm{x}_{\mathrm{t}}=\mathrm{u}_{\mathrm{t}} . \\
\mathrm{u}_{\mathrm{t}}=0.646 \mathrm{u}_{\mathrm{t}-1}+0.124 \mathrm{u}_{\mathrm{t}-1}+\varepsilon_{\mathrm{t}} \cdot 1
\end{gathered}
$$

Considering the confidence bands for the orders of integration of these selected models (in Table 1) we see that, for dividends, $d_{1}$ is significantly higher than 1 and $d_{2}$ significantly higher than 0 . For earnings and stock prices we cannot reject the null of $d_{1}=1$ and $d_{2}$ is significantly higher than 0 , and finally, for interest rates and bond yields we cannot reject the hypotheses of $\mathrm{d}_{1}=1$ and $\mathrm{d}_{2}=0$ at conventional statistical levels.

[INSERT TABLE 2 ABOUT HERE] 
Next we examine the case of a single pole at the long-run or zero frequency (Table 2). Here we notice that for dividends the order of integration is much higher than 1 if the disturbances are uncorrelated, and the unit root null cannot be rejected if they are autocorrelated. For the remaining of the series the unit root null cannot be rejected or, if it is rejected, it is in favour of mean reversion, with an order of integration significantly below 1. Using this specification, the selected model for dividends is the following: ${ }^{12}$

$$
(1-\mathrm{L})^{0.955} \mathrm{x}_{\mathrm{t}}=\mathrm{u}_{\mathrm{t}} ; \quad \mathrm{u}_{\mathrm{t}}=0.395 \mathrm{u}_{\mathrm{t}-1}-0.025 \mathrm{u}_{\mathrm{t}-2}+\varepsilon_{\mathrm{t}},
$$

In case of earnings, the chosen specification is:

$$
\begin{gathered}
y_{t}=-0.911-0.048 t+x_{t} ; \quad(1-L)^{0.872} x_{t}=u_{t} ; \\
u_{t}=0.250 u_{t-1}-0.585 u_{t-2}+\varepsilon_{t} .
\end{gathered}
$$

For interest rates,

$$
(1-\mathrm{L})^{0.702} \mathrm{x}_{\mathrm{t}}=\mathrm{u}_{\mathrm{t}} ; \quad \mathrm{u}_{\mathrm{t}}=0.318 \mathrm{u}_{\mathrm{t}-1}-0.053 \mathrm{u}_{\mathrm{t}-2}+\varepsilon_{\mathrm{t}}
$$

For government bond yields

$$
(1-\mathrm{L})^{0.892} \mathrm{x}_{\mathrm{t}}=\mathrm{u}_{\mathrm{t}} ; \quad \mathrm{u}_{\mathrm{t}}=-0.183 \mathrm{u}_{\mathrm{t}-1}+\varepsilon_{\mathrm{t}}
$$

and for the S\&P composite stock price index,

$$
\begin{array}{r}
y_{t}=-10.713+x_{t} ; \quad(1-L)^{0.926} x_{t}=u_{t} \\
u_{t}=0.147 u_{t-1}-0.120 u_{t-2}+\varepsilon_{t} .
\end{array}
$$

According to these models the five series are nonstationary, and the unit root hypothesis (d =1) cannot be rejected in any single case.

\subsection{The case of segmented trends}

\footnotetext{
${ }^{12}$ We use here the same autocorrelation tests and likelihood criteria as in the previous case.
} 
Next we allow for segmented trends, and assume that the five series exhibit a single break. ${ }^{13}$ A priori, we do not have any knowledge about the break date, and given the lack of procedures for estimating the break point in the context of the complex models presented above, we use a battery of methods, which are based on stationary I(0) (Bai, 1997, Bai and Perron, 1998), nonstationary I(1) (Zivot and Andrews, 1992), and fractional models (GilAlana, 2008; Wright, 2009).

\section{[INSERT TABLE 3 ABOUT HERE]}

Table 3 summarises the results concerning the break dates for each series on the basis of the different methods. One can see that, for example, assuming that the series contain unit roots, when performing the Bai's (1997) methodology on the differenced series, the break is found to occur in 1973 for earnings, interest rates and stock prices, and slightly later for dividends and bond yields. Using other $\mathrm{I}(0) / \mathrm{I}(1)$ methods (Zivot and Andrews, 1992; Lee and Strazicich, 2001) breaks are also found in the early 70s, and using the fractional approach of Gil-Alana (2008) we also obtain some evidence of a break in 1973 in four of the five series examined. On the other hand, Figure 1 also suggests that there might be a break around 1973, the time of the first oil price crisis. Based on this evidence we take 1973 as the break date in the five cases. We experimented with a change in the intercept, in the slope and in both of them, and came to the conclusion that an intercept change was the most plausible one for government bond yields, while for the remaining four series we allowed for a change in both intercept and slope after the break. Specifically, we consider a model of the form:

\footnotetext{
13 As mentioned earlier, multiple breaks could also be considered. However, we believe that the series examined in this paper can be adequately described including a single structural break. Note that allowing for multiple breaks would result in relatively short subsamples and inaccurate estimates of the coefficients.
} 


$$
y_{t}=\alpha_{1} I(t<1973)+\alpha_{2} I(t \geq 1973)+x_{t},
$$

for government bond yields, and

$$
y_{t}=\alpha_{1} I(t<1973)+\alpha_{2} I(t \geq 1973)+\beta t I(t \geq 1973)+x_{t},
$$

for the remaining four series, allowing two fractional structures as in (11) (in Table 4) and with a single fractional differencing polynomial at the zero frequency as in (12) (in Table $5):{ }^{14}$

\section{[INSERT TABLE 4 ABOUT HERE]}

Starting again with the case of two poles in the spectrum (i.e., using equation (11)), the selected model for dividends (with $\mathrm{T}^{*}=1973$ ) in Table 4 was:

$$
\begin{aligned}
& \mathrm{y}_{\mathrm{t}}=-91.289 \mathrm{I}\left(\mathrm{t}<\mathrm{T}^{*}\right)-51.396 \mathrm{I}\left(\mathrm{t} \geq \mathrm{T}^{*}\right)-1.375 \mathrm{t}\left(\mathrm{t} \geq \mathrm{T}^{*}\right)+\mathrm{x}_{\mathrm{t}} \\
& (1-\mathrm{L})^{1.05}\left(1-2 \cos \mathrm{w}_{11} \mathrm{~L}+\mathrm{L}^{2}\right)^{0.44} \mathrm{x}_{\mathrm{t}}=\mathrm{u}_{\mathrm{t}} ; \quad \mathrm{u}_{\mathrm{t}}=-0.076 \mathrm{u}_{\mathrm{t}-1}+\varepsilon_{\mathrm{t}} .
\end{aligned}
$$

For earnings,

$$
\begin{aligned}
& \mathrm{y}_{\mathrm{t}}=-262.180 \mathrm{I}\left(\mathrm{t}<\mathrm{T}^{*}\right)-198.181 \mathrm{I}\left(\mathrm{t} \geq \mathrm{T}^{*}\right)-4.360 \mathrm{tI}\left(\mathrm{t} \geq \mathrm{T}^{*}\right)+\mathrm{x}_{\mathrm{t}} \\
& (1-\mathrm{L})^{1.24}\left(1-2 \cos \mathrm{w}_{7} \mathrm{~L}+\mathrm{L}^{2}\right)^{0.66} \mathrm{x}_{\mathrm{t}}=\mathrm{u}_{\mathrm{t}} ; \quad \mathrm{u}_{\mathrm{t}}=0.251 \mathrm{u}_{\mathrm{t}-1}-0.255 \mathrm{u}_{\mathrm{t}-2}+\varepsilon_{\mathrm{t}}
\end{aligned}
$$

For interest rates,

$$
\begin{aligned}
& \mathrm{y}_{\mathrm{t}}=-82.952 \mathrm{I}\left(\mathrm{t}<\mathrm{T}^{*}\right)-113.644 \mathrm{I}\left(\mathrm{t} \geq \mathrm{T}^{*}\right)-5.173 \mathrm{tI}\left(\mathrm{t} \geq \mathrm{T}^{*}\right)+\mathrm{x}_{\mathrm{t}} \\
& (1-\mathrm{L})^{0.32}\left(1-2 \cos \mathrm{w}_{15} \mathrm{~L}+\mathrm{L}^{2}\right)^{1.29} \mathrm{x}_{\mathrm{t}}=\mathrm{u}_{\mathrm{t}} ; \quad \mathrm{u}_{\mathrm{t}}=-0.251 \mathrm{u}_{\mathrm{t}-1}+\varepsilon_{\mathrm{t}} .
\end{aligned}
$$

and for government bond yields,

$$
\begin{aligned}
& \mathrm{y}_{\mathrm{t}}=-26.576 \mathrm{I}\left(\mathrm{t}<\mathrm{T}^{*}\right)-33.123 \mathrm{I}\left(\mathrm{t} \geq \mathrm{T}^{*}\right)+\mathrm{x}_{\mathrm{t}} \\
& (1-\mathrm{L})^{0.96}\left(1-2 \cos \mathrm{w}_{3} \mathrm{~L}+\mathrm{L}^{2}\right)^{0.17} \mathrm{x}_{\mathrm{t}}=\mathrm{u}_{\mathrm{t}} ; \quad \mathrm{u}_{\mathrm{t}}=-0.109 \mathrm{u}_{\mathrm{t}-1}+\varepsilon_{\mathrm{t}}
\end{aligned}
$$

Finally, for stock prices:

\footnotetext{
${ }^{14}$ We also examined other break dates for the five series, and the coefficients in (13) and (14) were insignificant in the majority of the cases.
} 


$$
\begin{aligned}
& \mathrm{y}_{\mathrm{t}}=-9387.07 \mathrm{I}\left(\mathrm{t}<\mathrm{T}^{*}\right)-2273.11 \mathrm{I}\left(\mathrm{t} \geq \mathrm{T}^{*}\right)-163.843 \mathrm{tI}\left(\mathrm{t} \geq \mathrm{T}^{*}\right)+\mathrm{x}_{\mathrm{t}} \\
& (1-\mathrm{L})^{1.04}\left(1-2 \cos \mathrm{w}_{15} \mathrm{~L}+\mathrm{L}^{2}\right)^{0.40} \mathrm{x}_{\mathrm{t}}=\mathrm{u}_{\mathrm{t}} ; \quad \mathrm{u}_{\mathrm{t}}=-0.091 \mathrm{u}_{\mathrm{t}-1}+\varepsilon_{\mathrm{t}} .
\end{aligned}
$$

It can be seen that the number of periods per cycle (determined by $r$ in $\mathrm{w}_{\mathrm{r}}$ ) varies substantially depending on the series. Specifically, it is 11 for dividends, 7 for earnings, 15 for interest rates and stock prices, and 3 for government bond yields. The order of integration at the long-run or zero frequency is higher than the cyclical one for dividends, earnings, government bond yields and stock prices, while the opposite holds for interest rates. For earnings, $d_{1}$ is significantly higher than 1 , while $d_{2}$ is positive and in the interval $(0,1)$ for all series except the interest rates. Surprisingly, for this latter series $d_{1}$ is strictly smaller than 1 while $\mathrm{d}_{2}$ is significantly above 1 .

\section{[INSERT TABLE 5 ABOUT HERE]}

When we assume that there is a single pole occurring at the long-run or zero frequency (in Table 5), the deterministic terms are found to be statistically insignificant in some cases for dividends and earnings, while they are all significant in the case of interest rates, government bond yields and stock prices. The order of integration appears to be sensitive to the chosen specification for the disturbance term, especially for dividends and stock prices. For instance, for dividends, $\mathrm{d}_{1}$ is about 0.7 in case of autocorrelated errors, and it is about 1.1 with white noise disturbances. The selected models in this case are the following: for dividends,

$$
\begin{aligned}
& \mathrm{y}_{\mathrm{t}}=0.4885 \mathrm{I}\left(\mathrm{t}<\mathrm{T}^{*}\right)-0.2130 \mathrm{I}\left(\mathrm{t} \geq \mathrm{T}^{*}\right)+0.8652 \mathrm{tI}\left(\mathrm{t} \geq \mathrm{T}^{*}\right)+\mathrm{x}_{\mathrm{t}} \\
& (1-\mathrm{L})^{0.73} \mathrm{x}_{\mathrm{t}}=\mathrm{u}_{\mathrm{t}} ; \quad \mathrm{u}_{\mathrm{t}}=0.513 \mathrm{u}_{\mathrm{t}-1}+\varepsilon_{\mathrm{t}} .
\end{aligned}
$$

For earnings, 


$$
\begin{aligned}
& \mathrm{y}_{\mathrm{t}}=0.7104 \mathrm{I}\left(\mathrm{t}<\mathrm{T}^{*}\right)-0.6616 \mathrm{I}\left(\mathrm{t} \geq \mathrm{T}^{*}\right)+2.5332 \mathrm{tI}\left(\mathrm{t} \geq \mathrm{T}^{*}\right)+\mathrm{x}_{\mathrm{t}} \\
& (1-\mathrm{L})^{1.02} \mathrm{x}_{\mathrm{t}}=\mathrm{u}_{\mathrm{t}} ; \quad \mathrm{u}_{\mathrm{t}}=0.314 \mathrm{u}_{\mathrm{t}-1}-0.540 \mathrm{u}_{\mathrm{t}-2}+\varepsilon_{\mathrm{t}} .
\end{aligned}
$$

For interest rates,

$$
\begin{aligned}
& \mathrm{y}_{\mathrm{t}}=12.698 \mathrm{I}\left(\mathrm{t}<\mathrm{T}^{*}\right)+21.227 \mathrm{I}\left(\mathrm{t} \geq \mathrm{T}^{*}\right)-0.423 \mathrm{tI}\left(\mathrm{t} \geq \mathrm{T}^{*}\right)+\mathrm{x}_{\mathrm{t}} \\
& (1-\mathrm{L})^{0.66} \mathrm{x}_{\mathrm{t}}=\mathrm{u}_{\mathrm{t}} ; \quad \mathrm{u}_{\mathrm{t}}=0.228 \mathrm{u}_{\mathrm{t}-1}-0.074 \mathrm{u}_{\mathrm{t}-2}+\varepsilon_{\mathrm{t}} .
\end{aligned}
$$

For government bond yields,

$$
\begin{aligned}
& \mathrm{y}_{\mathrm{t}}=5.344 \mathrm{I}\left(\mathrm{t}<\mathrm{T}^{*}\right)+4.614 \mathrm{I}\left(\mathrm{t} \geq \mathrm{T}^{*}\right)+\mathrm{x}_{\mathrm{t}} \\
& (1-\mathrm{L})^{0.97} \mathrm{x}_{\mathrm{t}}=\mathrm{u}_{\mathrm{t}} ; \quad \mathrm{u}_{\mathrm{t}}=-0.156 \mathrm{u}_{\mathrm{t}-1}-0.012 \mathrm{u}_{\mathrm{t}-2}+\varepsilon_{\mathrm{t}}
\end{aligned}
$$

Finally, for stock prices

$$
\begin{aligned}
& \mathrm{y}_{\mathrm{t}}=10.039 \mathrm{I}\left(\mathrm{t}<\mathrm{T}^{*}\right)-101.490 \mathrm{I}\left(\mathrm{t} \geq \mathrm{T}^{*}\right)+55.964 \mathrm{tI}\left(\mathrm{t} \geq \mathrm{T}^{*}\right)+\mathrm{x}_{\mathrm{t}} \\
& (1-\mathrm{L})^{0.67} \mathrm{x}_{\mathrm{t}}=\mathrm{u}_{\mathrm{t}} ; \quad \mathrm{u}_{\mathrm{t}}=0.109 \mathrm{u}_{\mathrm{t}-1}-0.752 \mathrm{u}_{\mathrm{t}-2}+\varepsilon_{\mathrm{t}} .
\end{aligned}
$$

According to these specifications, the five variables (dividends, government bond yields, earnings, interest rates and stock prices) are nonstationary, with a fractional differencing parameter above 0.5 , and for two of them (dividends and stock price index) the unit root null is rejected in favour of mean reversion $(\mathrm{d}<1)$.

The final step is selecting the best model specification for each series. On the basis of the significance of the deterministic terms and of the fractional differencing parameters as well as the LR tests the most adequate specifications seem to be in all cases those with two fractional structures and a single structural break, as in equations (4A) - (4E). The results imply that $d_{1}$ (the order of integration at the long run or zero frequency) is significantly below 1 for interest rates; it is around 1 for dividends, bond yields and stock prices, and significantly above 1 in the case of earnings. With respect to the cyclical structure, the order of integration $\left(\mathrm{d}_{2}\right)$ is significantly positive although below 1 in all except one series (interest rates) where the order of cyclical fractional integration is strictly above 1 . 
Having selected the above models using within-sample criteria, we also briefly examine their forecasting performance. For each of the series we consider the four model specifications given by equations $(1 \mathrm{~A})-(5 \mathrm{E})$. First, we compute the $\mathrm{k}(=1,2, \ldots, 25)$-ahead prediction errors of each model, obtained by expanding the fractional polynomials in (5) and (7). We computed the Root Mean Squared Errors (RMSE) of each specification for each series. The results (not reported here for reasons of space, but available from the authors upon request) indicate that, for dividends, earnings and government bond yields, the model with a single fractional polynomial at the zero frequency (i.e., (2A), (2B) and (2D)) yields the most accurate predictions 1-2 periods ahead; however, for longer horizons, a model with a segmented trend (and also a fractional process at the zero frequency, i.e., (5A), (5B) and (5D)) outperforms the rival models. For interest rates, the results are slightly more ambiguous: the model with two polynomials (at the zero and the cyclical frequency, (1C)) seems to be the most adequate one in some cases, but a segmented model with a single polynomial at the zero frequency $(5 \mathrm{C})$ appears to be preferable in other cases. Finally, for stock prices, the model with two fractional differencing parameters (1E) produces the best results in the majority of cases. These results, however, are all based on the RMSE. This criterion and other methods such as the Mean Absolute Prediction Error (MAPE), Mean Squared Error (MSE), Mean Absolute Deviation (MAD), etc., are purely descriptive devices, and although there are several statistical tests for comparing different forecasting models (see, e.g. Diebold and Mariano, 1995; Harvey, Leybourne and Newbold, 1997; Ashley, 1998) it is well known that these methods have under some circumstances very low power, especially as regards non-linear models (see, e.g., Costantini and Kunst, 2011). Nevertheless, we computed the forecasting performance using the modified DM-tests as suggested by Harvey et al. (1997); the results (not reported) show that the models in Table 5 are to be preferred in most cases, especially based on the 5- and 
10-period ahead prediction horizons. Only for interest rates and stock prices do models (1C) and (1E) outperform (5C) and (5E) in some cases. We also evaluated the forecasting performance of our selected models by means of comparisons with standard ARIMA models with and without break. In particular, we use an $\operatorname{ARIMA}(2,1,0)$ for dividends; an $\operatorname{ARIMA}(0,1,2)$ for earnings; an $\operatorname{ARIMA}(0,1,2)$ for interest rates and an $\operatorname{ARIMA}(1,1,0)$ for bond yields and stock prices. In all cases, the fractional models outperform the ARIMA ones on the basis of the M-DM procedure.

Finally, we conducted a recursive experiment, leaving out first the last 25 observations, and then re-estimating the selected model for each series recursively, adding one observation at a time. The recursive estimates of the fractional differencing parameters in each case are displayed in Figures $2-6$. It can be seen that the parameters are very stable over time in all cases.

\section{[INSERT FIGURES 2 - 6 ABOUT HERE]}

\section{Conclusions}

In this paper we have employed a time series approach, not much previously used, for modelling long-run trends and cycles in financial time series data. The proposed model is general enough to include linear and segmented trends along with fractional integration at both zero and non-zero (cyclical) frequencies. It is based on a procedure developed by Robinson (1994) for testing stationary and nonstationary hypotheses. We use this framework to investigate the behaviour of five financial time series already examined in many earlier studies. Specifically, we use the annual dataset including dividends, earnings, interest rates, government bond yields and stock market prices, which was constructed (and is constantly updated) by Robert Shiller. 
The results can be summarised as follows. It appears that the five series of interest can be characterised in terms of long-memory processes with two poles in the spectrum, one corresponding to the long-run or zero frequency, and the other one to the cyclical component. The latter exhibits a periodicity ranging between 3 and 15 years depending on the series and the model considered. In general, the order of integration is higher at the zero frequency, implying that the degree of persistence is higher in this component. When a break is incorporated, the models outperform the linear ones in terms of both their insample performance based on goodness-of-fit (likelihood) measures and their forecasting accuracy, especially over longer horizons. Clearly, our findings have implications for the efficient market hypothesis and the debate on market anomalies, as in the case of the models where $\mathrm{d}$ is found to be smaller than 1 mean reversion takes place, suggesting some degree of inefficiency and predictability. The latter also characterises deviations from the random walk hypothesis when the order of integration of the series is higher than 1 and/or cases of serial (weak) correlation.

This paper can be extended in several directions. First, multiple cyclical structures of the form suggested by Ferrara and Guegan (2001) and others can be considered. In fact, the interaction between several cyclical (fractional) processes may produce autocorrelations decaying in a very complicated way that has not been much investigated yet. Other more complex non-linear structures (like the Threshold AutoRegressive, TAR, Momentum Threshold AutoRegressive, M-TAR or Smooth Transition Autoregressive, STAR-form (see, e.g. Enders and Granger, 1998; Enders and Siklos, 2001; Skalin and Teräsvirta, 2002; etc.) can also be included in the regression model (1), and their interaction with the fractional structures is another issue that should be examined in future research. 


\section{Appendix}

The test statistic proposed by Robinson (1994) for testing $H_{o}(8)$ in the model given by equations (1) - (3) is given by:

$$
\hat{R}=\frac{T}{\hat{\sigma}^{4}} \hat{a}^{\prime} \hat{A}^{-1} \hat{a}
$$

where $\mathrm{T}$ is the sample size, and

$$
\begin{gathered}
\hat{a}=\frac{-2 \pi}{T} \sum_{j}^{*} \psi\left(\lambda_{j}\right) g\left(\lambda_{j} ; \hat{\tau}\right)^{-1} I\left(\lambda_{j}\right) ; \quad \hat{\sigma}^{2}=\sigma^{2}(\hat{\tau})=\frac{2 \pi}{T} \sum_{j=1}^{T-1} g\left(\lambda_{j} ; \hat{\tau}\right)^{-1} I\left(\lambda_{j}\right), \\
\hat{A}=\frac{2}{T}\left(\sum_{j}^{*} \psi\left(\lambda_{j}\right) \psi\left(\lambda_{j}\right)^{\prime}-\sum_{j}^{*} \psi\left(\lambda_{j}\right) \hat{\varepsilon}\left(\lambda_{j}\right)^{\prime}\left(\sum_{j}^{*} \hat{\varepsilon}\left(\lambda_{j}\right) \hat{\varepsilon}\left(\lambda_{j}\right)^{\prime}\right)^{-1} \sum_{j}^{*} \hat{\varepsilon}\left(\lambda_{j}\right) \psi\left(\lambda_{j}\right)^{\prime}\right) \\
\psi\left(\lambda_{j}\right)^{\prime}=\left\lfloor\psi_{1}\left(\lambda_{j}\right), \psi_{2}\left(\lambda_{j}\right)\right] ; \quad \hat{\varepsilon}\left(\lambda_{j}\right)=\frac{\partial}{\partial \tau} \log g\left(\lambda_{j} ; \hat{\tau}\right) ; \quad \psi_{1}\left(\lambda_{j}\right)=\log \left|2 \sin \frac{\lambda_{j}}{2}\right| ;
\end{gathered}
$$

$\psi_{2}\left(\lambda_{j}\right)=\log \left|2\left(\cos \lambda_{j}-\cos w_{r}\right)\right|$, with $\lambda_{\mathrm{j}}=2 \pi \mathrm{j} / \mathrm{T}$, and the summation in $*$ is over all frequencies which are bounded in the spectrum. $I\left(\lambda_{j}\right)$ is the periodogram of $\hat{u}_{t}=(1-L)^{d_{1 o}}\left(1-2 \cos w_{r} L+L^{2}\right)^{d} 2 o y_{t}-\hat{\beta}^{\prime} \bar{z}_{t}$, with

$$
\hat{\beta}=\left(\sum_{t=1}^{T} \bar{z}_{t} \bar{z}_{t}\right)^{-1} \sum_{t=1}^{T} \bar{z}_{t}(1-L)^{d_{1} o}\left(1-2 \cos w_{r} L+L^{2}\right)^{d} 2 o y_{t}
$$

$\bar{z}_{t}=(1-L)^{d_{1 o}}\left(1-2 \cos w_{r} L+L^{2}\right)^{d_{2 o}} z_{t}$, evaluated at $\lambda_{\mathrm{j}}=2 \pi \mathrm{j} / \mathrm{T}$ and $\hat{\tau}=$ $\arg \min _{\tau \in T^{*}} \sigma^{2}(\tau)$, with $\mathrm{T}^{*}$ as a suitable subset of the $\mathrm{R}^{\mathrm{q}}$ Euclidean space. Finally, the function $\mathrm{g}$ above is a known function coming from the spectral density of $\mathrm{u}_{\mathrm{t}}$ :

$$
f(\lambda)=\frac{\sigma^{2}}{2 \pi} g(\lambda ; \tau), \quad-\pi<\lambda \leq \pi
$$

Note that these tests are purely parametric and, therefore, they require specific modelling assumptions about the short-memory specification of $\mathrm{u}_{\mathrm{t}}$. Thus, if $\mathrm{u}_{\mathrm{t}}$ is white noise, $\mathrm{g} \equiv 1$, 
and if $u_{t}$ is an AR process of the form $\phi(L) u_{t}=\varepsilon_{t}, g=\left|\phi\left(e^{i \lambda}\right)\right|^{-2}$, with $\sigma^{2}=V\left(\varepsilon_{t}\right)$, so that the AR coefficients are a function of $\tau$. 


\section{References}

Ahtola, J.. and Tiao, G.C., 1987, Distributions of least squares estimators of autoregressive parameters for a process with complex roots on the unit circle, Journal of Time Series Analysis 8, 1-14.

Anh, V.V., V.P. Knopova and N.N. Leonenko, 2004, Continuous-time stochastic processes with cyclical long range dependence, Australian and New Zeeland Journal of Statistics 46, 275-296.

Arteche, J., 2002, Semiparametric robust tests on seasonal or cyclical long memory time series, Journal of Time Series Analysis 23, 251-268.

Arteche, J. and P.M. Robinson, 2000, Semiparametric inference in seasonal and cyclical long memory processes, Journal of Time Series Analysis 21, 1-27.

Ashley, R., 1998, A new technique for postsample model selection and validation, Journal of Economics Dynamics and Control 22, 647-665.

Bai, J., 1997, Estimation of a change point in multiple regression models, The Review of Economics and Statistics 79, 551-563.

Bai, J. and P. Perron, 1998, Estimating and testing linear models with multiple structural changes, Econometrica 66, 47-78.

Baillie, R.T., 1996, Long memory processes and fractional integration in econometrics, Journal of Econometrics 73, 1, 5-59.

Barkoulas, J.T. and C.F. Baum, 1996, Long term dependence in stock returns. Economics Letters 53, 253-259.

Barkoulas, J.T., C.F. Baum and N. Travlos, 2000, Long memory in the Greek stock market. Applied Financial Economics 10, 177-184.

Baxter, M. and R.G. King, 1999, Measuring business cycles approximate band-pass filters for economic time series, The Review of Economics and Statistics 81, 575-593. 
Beaudry P. and G. Koop, 1993, Do recessions permanently change output?, Journal of Monetary Economics 31, 149-163.

Bernanke, B.S., M. Gertler, and S. Gilchrist, 1999, The Financial Accelerator in a Quantitative Business Cycle Framework, in Handbook of Macroeconomics, Volume 1C, Handbooks in Economics, vol. 15. Amsterdam: Elsevier, pp. 1341-93.

Bierens, H.J., 1997, Testing the unit root with drift hypothesis against nonlinear trend stationarity with an application to the US price level and interest rate, Journal of Econometrics 81, 29-64.

Bierens, H.J., 2001, Complex unit roots and business cycles: Are they real? Econometric Theory 17, 962-983.

Box, G.E.P. and D.A. Pierce, 1970, Distribution of residual autocorrelations in autoregressive integrated moving average time series models, Journal of the American Statistical Association 65, 1509-1526.

Burnside, A.C., 1998, Detrending and business cycle facts. A comment, Journal of Monetary Economics 41, 513-532.

Candelon, B. and L. A. Gil-Alana, 2004, Fractional integration and business cycle features, Empirical Economics 29, 1-17.

Canova, F., 1998, Detrending and business cycle facts. A user's guide, Journal of Monetary Economics 41, 533-540.

Caporale, G.M. and L.A. Gil-Alana, 2002, Fractional integration and mean reversion in stock prices, Quarterly Review of Economics and Finance 42, 599-609.

Caporale, G.M. and L.A. Gil-Alana, 2006, Long memory at the long run and cyclical frequencies. Modelling real wages in England: 1260-1994, Empirical Economics 31(1), 8392. 
Caporale, G.M. and L.A. Gil-Alana, 2007, Long run and cyclical dynamics in the US stock market, CESifo Working Paper no. 2046.

Cheung, Y.- W. and K.S. Lai, 1995, A search for long memory in international stock market returns. Journal of International Money and Finance 14, 597-615.

Costantini, M. and R.M. Künst, 2011, On the usefulness of the Diebold and Mariano test in the selection of prediction models, Econometric Series 276, Institute for Advanced Studies. Crato, N., 1994, Some international evidence regarding the stochastic behaviour of stock returns. Applied Financial Economics 4, 33-39.

Diebold, F.X. and R.S. Mariano, 1995, Comparing predictive accuracy, Journal of Business, Economics and Statistics 13, 253-263.

Diebold, F.X. and G.D. Rudebusch, 1989, Long memory and persistence in the aggregate output. Journal of Monetary Economics 24, 189-209.

Dittmar, R.F., 2002, Nonlinear Pricing Kernels, Kurtosis Preference, and Evidence from the Cross Section of Equity Returns, Journal of Finance, American Finance Association, vol. 57(1), 369-403.

Enders, W. and Granger, C.W.J., 1998. Unit root tests and asymmetric adjustment with an example using the term structure of interest rates. Journal of the American Statistical Association 16(3), 304-311.

Enders, W. and Siklos, P., 2001, Cointegration and threshold adjustment. Journal of Business and Economic Statistics 19(2), 166-176.

Fama, E.F., 1970, Efficient capital markets: a review of theory and empirical work, Journal of Finance 25, 383-417.

Fama, E.F. and K.R. French, 1988, Permanent and transitory components of stock prices, Journal of Political Economy 96, 246-273. 
Farmer, R., 2012, The stock market crash of 2008 caused the Great Recession. Theory and evidence, Journal of Economic Dynamics and Control 36, 693-707.

Ferrara, L. and D. Guegan, 2001, Forecasting with k-factor Gegenbauer processes. Theory and Applications. Journal of Forecasting 20, 581-601.

Gil-Alana, L.A., 2001, Testing stochastic cycles in macroeconomic time series. Journal of Time Series Analysis 22, 411-430.

Gil-Alana, L.A., 2006, Fractional integration in daily stock market returns. Review of Financial Economics 15, 28-48.

Gil-Alana, L.A., 2007a, Testing the existence of multiple cycles in financial and economic time series. Annals of Economics and Finance 1, 1-20.

Gil-Alana, L.A., 2007b, Long run and cyclical strong dependence in macroeconomic time series. Nelson and Plosser revisited, Empirica 34(2), 139-154.

Gil-Alana, L.A., 2008, Fractional integration and structural breaks at unknown periods of time, Journal of Time Series Analysis 29, 163-185.

Gil-Alana, L.A. and P.M. Robinson, 1997, Testing of unit roots and other nonstationary hypotheses in macroeconomic time series. Journal of Econometrics 80, 241-268.

Giraitis, L., J. Hidalgo and P.M. Robinson, 2001, Gaussian estimation of parametric spectral density with unknown pole, Annals of Statistics 29, 987-1023.

Gray, H.L., Yhang, N. and Woodward, W.A., 1989, On generalized fractional processes, Journal of Time Series Analysis 10, 233-257.

Gray, H.L., Yhang, N. and Woodward, W.A., 1994, On generalized fractional processes. A correction, Journal of Time Series Analysis 15, 561-562.

Hamming, R. W. (1973) Numerical Methods for Scientists and Engineers, Dover. Harvey, A., 1985, Trends and cycles in macroeconomic time series, Journal of Business and Economics Statistics 3, 216-227. 
Harvey, D.I., S.J. Leybourne and P. Newbold, 1997, Testing the equality of prediction mean squared errors, International Journal of Forecasting 13, 281-291.

Hassler, U., 1994, Regression of spectral estimators with fractionally integrated time series, Journal of Time Series Analysis 14, 360-379.

Hassler, U., P.M.M. Rodrigues and A. Rubia, 2009, Testing for the general unit root hypothesis in the time domain, Econometric Theory 25, 1793-1828.

Henry, O.T., 2002, Long memory in stock returns. Some international evidence. Applied Financial Economics 12, 725-729.

Hidalgo, J., 2005, Semiparametric estimation for stationary processes whose spectra have an unknown pole, Annals of Statistics 35, 1843-1889.

Hidalgo, J. and P. Soulier, 2004, Estimation of the location and exponent of the spectral singularity of a long memory process, Journal of Time Series Analysis 25, 55-81.

Hosking, J.R.M., 1981, Fractional differencing, Biometrika 68, 165-176.

Hosking, J.R.M., 1984, Modelling persistence in hydrological time series using fractional differencing, Water Resources Research 20, 1898-1908.

Hosoya, Y., 1997, A limit theorem for long run dependence and statistical inference on related models, Annals of Statistics 25, 105-137.

Hossein, A. and K. Sonnie, 2008, Evaluating a nonlinear asset pricing model on international data, International Review of Financial Analysis 17, 3, 604-621.

King, R.G. and S.T. Rebelo, 1999, Resucitating real business cycles, in J.B. Taylor and M. Woodford eds., Handbook in Macroeconomics 1, 928-1001.

Lee, J. and M.C. Strazicich, 2001, Break point estimation and spurious rejections with endogenous unit root tests, Oxford Bulletin of Economics and Statistics 63, 535-558.

Lobato, I. and C. Velasco, 2007, Efficient Wald test for fractional unit roots, Econometrica $75,575-589$. 
Ljung, G.M. and G.E.P. Box, 1978, On a measure of lack of fit in time series models, Biometrika 65, 297-303.

Magnus, W., Oberhettinger, F. and R.P. Soni, 1966, Formulas and theorems for the special functions of mathematical physics. Springer, Berlin.

Ooms, M., 1997, Flexible seasonal long memory and economic time series, Econometrics Institute Report 134, University of Roterdam, Econometrics.

Pesaran, M.H. and S.M Potter, 1997, A floor and ceiling model of US output, Journal of Economics Dynamics and Control 21, 661-695.

Peters, E.E., 1994, Fractal Market Analysis: Applying Chaos Theory to Investment and Economics, John Wiley \& Sons, New York.

Poterba, J.M. and L.H. Summers, 1988, Mean reversion in stock prices: evidence and implications, Journal of Financial Economics 22, 27-59.

Rainville, E.D., 1960, Special functions, MacMillan, New York.

Robinson, P.M., 1994, Efficient tests of nonstationary hypotheses, Journal of the American Statistical Association 89, 1420-1437.

Sadek, N. and A. Khotanzad, 2004, K-factor Gegenbauer ARMA process for network traffic simulation. Computers and Communications 2, 963-968.

Sadique, S. and P. Silvapulle, 2001, Long-term memory in stock market returns. International evidence. International Journal of Finance and Economics 6, 59-67.

Shiller, R., 1989, Market Volatility, Cambridge, Mass.: MIT Press.

Skalin, J. and Teräsvirta, T., 2002. Modelling asymmetries and moving equilibria in unemployment rates. Macroeconomic Dynamics, 6, 202-241.

Soares, L.J. and L.R. Souza, 2006, Forecasting electricity demand using generalized long memory, International Journal of Forecasting 22, 17-28. 
Sowell, F., 1992, Maximum likelihood estimation of stationary univariate fractionally integrated time series models, Journal of Econometrics 53, 165-188.

Stock, J.H. and M.W. Watson, 2003, Has the business cycle changed? Proceedings of the Federal Reserve Bank of Kansas City, Symposium "Monetary Policy and Uncertainty", pages 9-56.

Stock, J.H. and M.W. Watson, 2005, Understanding changes in international business cycle dynamics, Journal of the European Economic Association, MIT Press 35, 968-1006.

Summers, L.H., 1986, Does the stock market rationally reflect fundamental values?, Journal of Finance 41, 591-601.

Tanaka, K., 1999, The nonstationary fractional unit root, Econometric Theory 15, 549-582. Tolvi, J., 2003, Long memory and outliers in stock market returns. Applied Financial Economics 13, 495-502.

Wright, J., 2009, Testing for a structural break at unknown date with long memory disturbances, Journal of Time Series Analysis 19, 369-376.

Zivot, E. and D.W.K. Andrews, 1992, Further evidence on the Great Crash, the Oil Price shock and the unit root hypothesis, Journal of Business and Economic Statistics 10, 251270. 
Figure 1: Time series plots

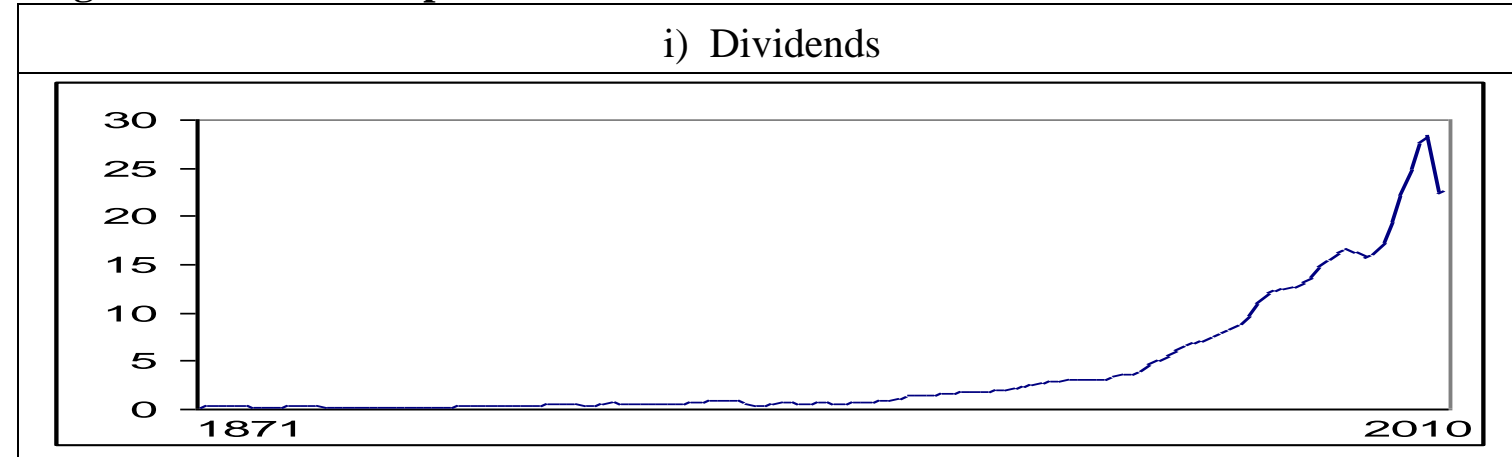

ii) Earnings

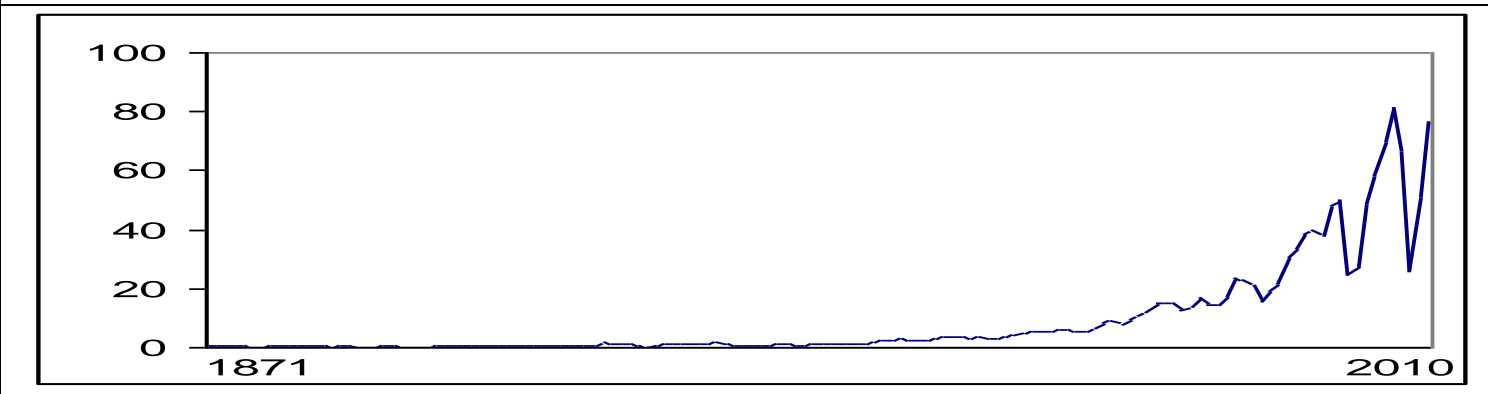

iii) One-year interest rate

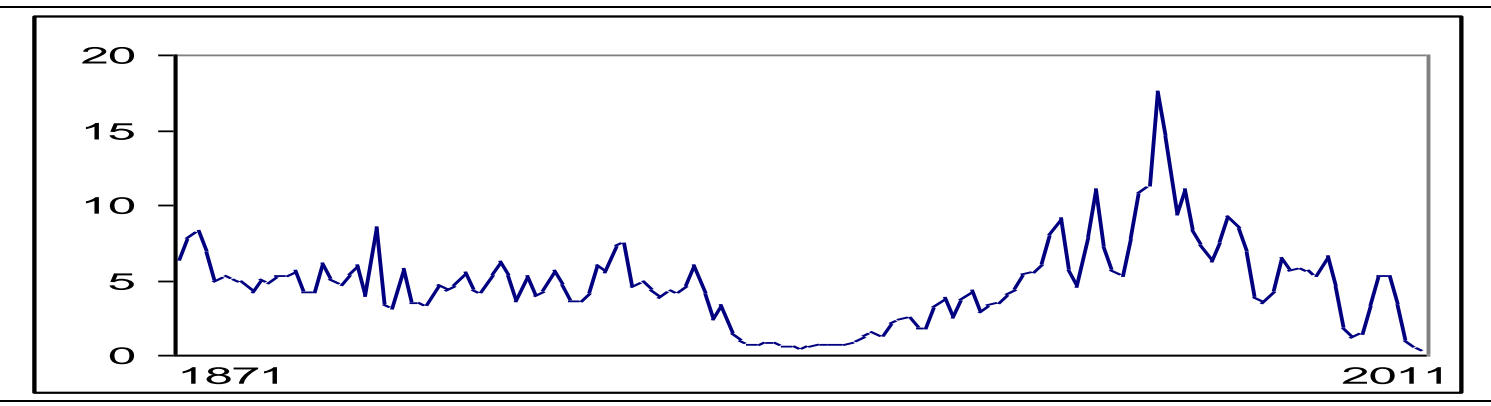

iv) Long-term government bond yield

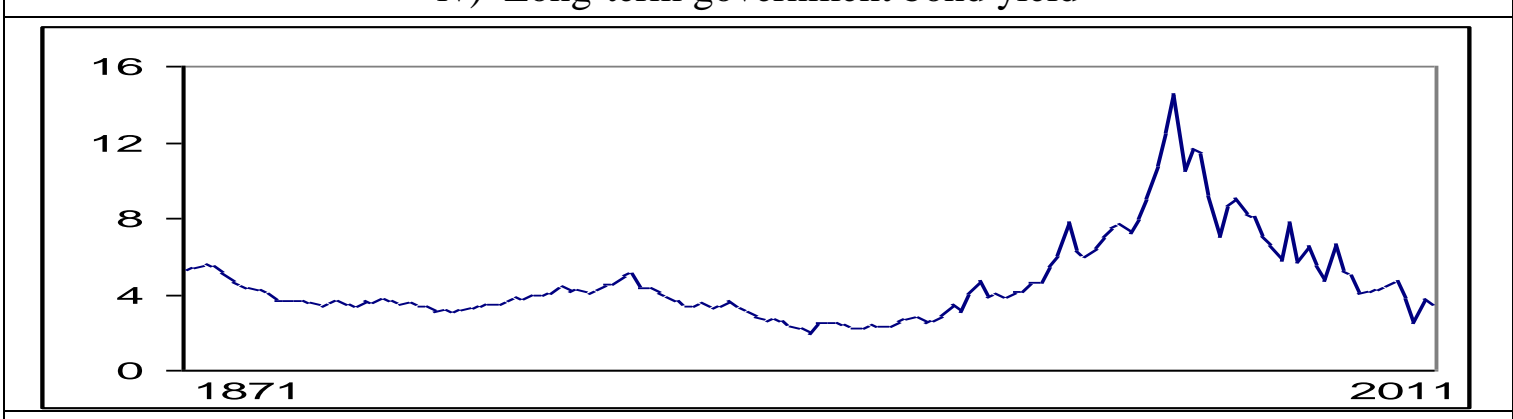

v) S\&P Composite stock price index

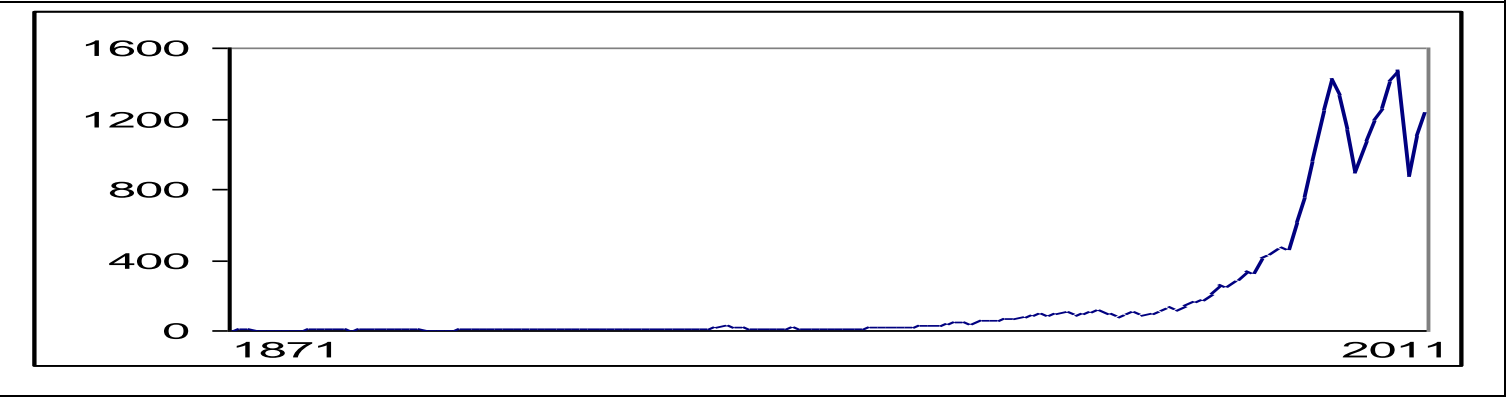


Table 1: Coefficient estimates with two fractional structures

\begin{tabular}{|c|c|c|c|c|c|c|c|}
\hline \multicolumn{8}{|c|}{ 1a) Series: Dividends } \\
\hline & $\alpha$ & $\beta$ & $\mathrm{d}_{1}$ & $\mathrm{r}$ & $\mathrm{d}_{2}$ & $\rho_{1}$ & $\rho_{2}$ \\
\hline $\operatorname{AR}(2)$ with time trend & $\begin{array}{c}-563.39 \\
(-40.17)\end{array}$ & $\begin{array}{l}-0.209 \\
(-1.23)\end{array}$ & $\begin{array}{c}0.03 \\
{[-0.08,0.14]}\end{array}$ & 8 & $\begin{array}{c}0.57 \\
{[0.49,1.50]}\end{array}$ & 0.882 & -0.258 \\
\hline $\mathrm{AR}(2)$ with an intercept & $\begin{array}{c}-6.764 \\
(-3.66)\end{array}$ & --- & $\begin{array}{c}1.22 \\
{[0.79,1.57]}\end{array}$ & 15 & $\begin{array}{c}0.98 \\
{[0.33,1.35]}\end{array}$ & -0.731 & 1.297 \\
\hline AR(2) with no regressors & --- & --- & $\begin{array}{c}1.11 \\
{[0.44,1.47]}\end{array}$ & 9 & $\begin{array}{c}0.27 \\
{[-.05,0.66}\end{array}$ & -0.443 & -0.478 \\
\hline $\mathrm{AR}(1)$ with time trend & $\begin{array}{c}-13.167 \\
(-3.77)\end{array}$ & $\begin{array}{c}-40.903 \\
(-75.87)\end{array}$ & $\begin{array}{c}1.03 \\
{[0.92,1.16]}\end{array}$ & 13 & $\begin{array}{c}0.76 \\
{[0.53,1.28]}\end{array}$ & -0.291 & --- \\
\hline AR(1) with an intercept & $\begin{array}{c}-14.211 \\
(-9.36)\end{array}$ & --- & $\begin{array}{c}1.41 \\
{[1.32,1.82]}\end{array}$ & 3 & $\begin{array}{c}0.63 \\
{[0.47,0.77]}\end{array}$ & 0.053 & --- \\
\hline AR(1) with no regressors & --- & --- & $\begin{array}{c}1.14 \\
{[1.01,1.51]}\end{array}$ & 5 & $\begin{array}{c}0.09 \\
{[0.02,0.15]}\end{array}$ & 0.178 & --- \\
\hline White noise with trend & $\begin{array}{c}-500.16 \\
(-30.54)\end{array}$ & $\begin{array}{c}-1.981 \\
(-9.85)\end{array}$ & $\begin{array}{c}0.13 \\
{[0.07,0.16]}\end{array}$ & 15 & $\begin{array}{c}1.06 \\
{[0.99,1.14]}\end{array}$ & --- & --- \\
\hline White noise + intercept $* * *$ & $\begin{array}{c}-77.061 \\
(-6.013)\end{array}$ & --- & $\begin{array}{c}1.35 \\
{[1.22,1.67]}\end{array}$ & 10 & $\begin{array}{c}0.41 \\
{[0.17,0.70]}\end{array}$ & --- & --- \\
\hline White noise with no reg. & --- & --- & $\begin{array}{c}1.15 \\
{[1.09,1.38]}\end{array}$ & 12 & $\begin{array}{c}0.53 \\
{[0.44,0.76]}\end{array}$ & --- & --- \\
\hline \multicolumn{8}{|c|}{ 1b) Series: Earnings } \\
\hline & $\alpha$ & $\beta$ & $\mathrm{d}_{1}$ & $\mathrm{r}$ & $\mathrm{d}_{2}$ & $\rho_{1}$ & $\rho_{2}$ \\
\hline $\operatorname{AR}(2)$ with time trend & $\begin{array}{c}-41.730 \\
(-1.621)\end{array}$ & \begin{tabular}{|l|}
-84.41 \\
$(-27.40)$ \\
\end{tabular} & $\begin{array}{c}0.99 \\
{[0.81,1.22]}\end{array}$ & 8 & $\begin{array}{c}0.58 \\
{[0.30,0.93]}\end{array}$ & 0.148 & -0.175 \\
\hline $\operatorname{AR}(2)$ with an intercept ${ }^{* * * *}$ & $\begin{array}{c}-94.241 \\
(-0.813)\end{array}$ & --- & $\begin{array}{c}1.08 \\
{[0.98,1.77]}\end{array}$ & 7 & $\begin{array}{c}0.35 \\
{[0.10,0.49]}\end{array}$ & 0.953 & -0.695 \\
\hline $\operatorname{AR}(2)$ with no regressors & --- & --- & $\begin{array}{c}1.04 \\
{[0.60,1.74]}\end{array}$ & 8 & $\begin{array}{c}0.11 \\
{[-0.33,0.64]}\end{array}$ & 0.195 & 0.417 \\
\hline $\mathrm{AR}(1)$ with time trend & $\begin{array}{l}4.049 \\
(0.143)\end{array}$ & \begin{tabular}{|c|}
-185.4 \\
$(-36.90)$ \\
\end{tabular} & $\begin{array}{c}1.23 \\
{[0.97,1.45]}\end{array}$ & 11 & $\begin{array}{c}0.57 \\
{[0.12,0.88]}\end{array}$ & 0.264 & --- \\
\hline $\mathrm{AR}(1)$ with an intercept & $\begin{array}{c}1191.41 \\
(15.311)\end{array}$ & --- & $\begin{array}{c}1.18 \\
{[0.97,1.48]}\end{array}$ & 2 & $\begin{array}{c}0.60 \\
{[0.34,0.98]}\end{array}$ & 0.827 & --- \\
\hline $\operatorname{AR}(1)$ with no regressors & --- & --- & $\begin{array}{c}0.77 \\
{[0.28,1.21]}\end{array}$ & 3 & $\begin{array}{c}0.10 \\
{[-0.11,0.32]}\end{array}$ & 0.261 & --- \\
\hline White noise with trend & $\begin{array}{c}-95.908 \\
(-36.31)\end{array}$ & $\begin{array}{l}-8.750 \\
(-6.45)\end{array}$ & $\begin{array}{c}0.94 \\
{[0.89,1.14]}\end{array}$ & 10 & $\begin{array}{c}0.67 \\
{[0.54,0.94]}\end{array}$ & --- & --- \\
\hline White noise with intercept & $\begin{array}{c}62.073 \\
(-1.06)\end{array}$ & --- & $\begin{array}{c}1.14 \\
{[1.02,1.39]}\end{array}$ & 8 & $\begin{array}{c}0.31 \\
{[0.12,0.62]}\end{array}$ & --- & --- \\
\hline White noise with no reg. & --- & --- & $\begin{array}{c}0.90 \\
{[0.75,1.20]}\end{array}$ & 6 & $\begin{array}{c}0.27 \\
{[0.01,0.52]}\end{array}$ & --- & --- \\
\hline
\end{tabular}

(continued) 


\begin{tabular}{|c|c|c|c|c|c|c|c|}
\hline \multicolumn{8}{|c|}{ 1c) Series: Interest rates } \\
\hline & $\alpha$ & $\beta$ & $\mathrm{d}_{1}$ & $\mathrm{r}$ & $\mathrm{d}_{2}$ & $\rho_{1}$ & $\rho_{2}$ \\
\hline $\operatorname{AR}(2)$ with time trend & $\begin{array}{c}-11.840 \\
(-1.26)\end{array}$ & $\begin{array}{c}-2.925 \\
(-0.09)\end{array}$ & $\begin{array}{c}0.86 \\
{[0.56,1.22]}\end{array}$ & 12 & $\begin{array}{c}0.30 \\
{[-0.09,0.14]}\end{array}$ & -0.348 & 0.785 \\
\hline $\mathrm{AR}(2)$ with an intercept & $\begin{array}{c}-205.62 \\
(-0.49)\end{array}$ & --- & $\begin{array}{c}0.75 \\
{[0.40,1.33]}\end{array}$ & 4 & $\begin{array}{c}0.21 \\
{[-0.19,0.45]}\end{array}$ & 0.438 & 0.024 \\
\hline$A R(2)$ and no regressors $* * *$ & --- & --- & $\begin{array}{c}0.77 \\
{[0.17,1.10]} \\
\end{array}$ & 8 & $\begin{array}{c}0.23 \\
{[-0.17,0.88]}\end{array}$ & 0.082 & -0.678 \\
\hline $\mathrm{AR}(1)$ with time trend & $\begin{array}{c}72.541 \\
(4.32)\end{array}$ & $\begin{array}{l}14.870 \\
(42.63)\end{array}$ & $\begin{array}{c}1.15 \\
{[0.77,1.42]}\end{array}$ & 3 & $\begin{array}{c}0.09 \\
{[-0.27,0.32]}\end{array}$ & 0.070 & --- \\
\hline AR(1) with an intercept & $\begin{array}{c}-75.046 \\
(-6.45) \\
\end{array}$ & --- & $\begin{array}{c}1.32 \\
{[0.88,1.65]} \\
\end{array}$ & 2 & $\begin{array}{c}0.13 \\
{[-0.05,0.69]} \\
\end{array}$ & -0.158 & --- \\
\hline $\operatorname{AR}(1)$ with no regressors & --- & --- & $\begin{array}{c}0.77 \\
{[0.411 .15]}\end{array}$ & 8 & $\begin{array}{c}\mathbf{0 . 0 2} \\
{[-0.17,0.32]}\end{array}$ & 0.067 & --- \\
\hline White noise with trend & $\begin{array}{c}-18.966 \\
(-1.82)\end{array}$ & $\begin{array}{c}4.408 \\
(26.370)\end{array}$ & $\begin{array}{c}1.13 \\
{[0.76,1.44]}\end{array}$ & 15 & $\begin{array}{c}0.07 \\
{[-0.22,0.43]}\end{array}$ & --- & --- \\
\hline White noise + intercept & $\begin{array}{c}-47.415 \\
(-6.99) \\
\end{array}$ & --- & $\begin{array}{c}1.41 \\
{[1.01,1.86]}\end{array}$ & 3 & $\begin{array}{c}\mathbf{0 . 0 3} \\
{[-0.34,0.55]}\end{array}$ & --- & --- \\
\hline White noise with no reg. & --- & --- & $\begin{array}{c}1.01 \\
{[0.72,1.54]}\end{array}$ & 15 & $\begin{array}{c}0.15 \\
{[-0.26,0.44]}\end{array}$ & --- & --- \\
\hline \multicolumn{8}{|c|}{ 1d) Series: Government bond yields } \\
\hline & $\alpha$ & $\beta$ & $\mathrm{d}_{1}$ & $\mathrm{r}$ & $\mathrm{d}_{2}$ & $\rho_{1}$ & $\rho_{2}$ \\
\hline $\operatorname{AR}(2)$ with time trend & $\begin{array}{c}-11.840 \\
(-1.26)\end{array}$ & $\begin{array}{c}-2.925 \\
(-0.09)\end{array}$ & $\begin{array}{c}0.86 \\
{[0.56,1.22]}\end{array}$ & 8 & $\begin{array}{c}0.30 \\
{[-0.09,0.14]}\end{array}$ & -0.348 & 0.785 \\
\hline $\operatorname{AR}(2)$ with an intercept & $\begin{array}{c}-14.732 \\
(-0.08)\end{array}$ & --- & $\begin{array}{c}0.97 \\
{[0.66,1.29]}\end{array}$ & 11 & $\begin{array}{c}0.52 \\
{[0.20,1.04]}\end{array}$ & -0.260 & 0.683 \\
\hline $\operatorname{AR}(2)$ with no regressors & --- & --- & $\begin{array}{c}0.77 \\
{[0.17,1.10]}\end{array}$ & 4 & $\begin{array}{c}0.23 \\
{[-0.17,0.88]}\end{array}$ & 0.082 & -0.678 \\
\hline $\mathrm{AR}(1)$ with time trend & $\begin{array}{c}-11.840 \\
(-1.26)\end{array}$ & $\begin{array}{l}-2.925 \\
(-0.09)\end{array}$ & $\begin{array}{c}0.86 \\
{[0.56,1.22]}\end{array}$ & 14 & $\begin{array}{c}0.30 \\
{[-0.09,0.14]}\end{array}$ & -0.348 & 0.785 \\
\hline $\operatorname{AR}(1)$ with an intercept $* * *$ & $\begin{array}{c}-117.56 \\
(-8.54)\end{array}$ & --- & $\begin{array}{c}1.08 \\
{[0.94,1.21]}\end{array}$ & 8 & $\begin{array}{c}0.24 \\
{[-0.05,0.85]}\end{array}$ & 0.133 & --- \\
\hline AR(1) with no regressors & --- & --- & $\begin{array}{c}0.53 \\
{[0.12,0.88]}\end{array}$ & 3 & $\begin{array}{c}0.08 \\
{[-0.14,0.34]}\end{array}$ & 0.192 & --- \\
\hline White noise with trend & $\begin{array}{c}-11.152 \\
(-1295)\end{array}$ & $\begin{array}{l}-0.491 \\
(-7.158)\end{array}$ & $\begin{array}{c}0.78 \\
{[0.66,0.89]}\end{array}$ & 15 & $\begin{array}{c}0.09 \\
{[-0.05,0.38]}\end{array}$ & --- & --- \\
\hline White noise + intercept & $\begin{array}{c}-280.53 \\
(-6.50) \\
\end{array}$ & --- & $\begin{array}{c}1.15 \\
{[0.97,1.53]}\end{array}$ & 3 & $\begin{array}{c}0.05 \\
{[-0.07,0.28]}\end{array}$ & --- & -- \\
\hline White noise with no reg. & --- & --- & $\begin{array}{c}0.74 \\
{[0.49,0.98]}\end{array}$ & 2 & $\begin{array}{c}\mathbf{0 . 0 2} \\
{[-\mathbf{0 . 1 5}, \mathbf{0 . 2 7 ]}}\end{array}$ & --- & -- \\
\hline
\end{tabular}

(continued) 


\begin{tabular}{|c|c|c|c|c|c|c|c|}
\hline \multicolumn{8}{|c|}{ 1e) Series: S\&P composite stock price index } \\
\hline & $\alpha$ & $\mathrm{B}$ & $\mathrm{d}_{1}$ & $\mathrm{r}$ & $d_{2}$ & $\rho_{1}$ & $\rho_{2}$ \\
\hline $\operatorname{AR}(2)$ with time trend & $\begin{array}{c}812.02 \\
(1.71)\end{array}$ & $\begin{array}{c}-1463.9 \\
(-2.04)\end{array}$ & $\begin{array}{c}1.08 \\
{[0.88,1.23]}\end{array}$ & 11 & $\begin{array}{c}0.20 \\
{[0.03,0.54]}\end{array}$ & 0.044 & 0.454 \\
\hline $\operatorname{AR}(2)$ with an intercept $* * *$ & $\begin{array}{c}-1506.6 \\
(-0.27)\end{array}$ & --- & $\begin{array}{c}1.11 \\
{[0.89,1.34]}\end{array}$ & 8 & $\begin{array}{c}0.50 \\
{[0.32,0.74]}\end{array}$ & 0.646 & 0.124 \\
\hline $\operatorname{AR}(2)$ with no regressors & --- & --- & $\begin{array}{c}0.70 \\
{[0.43,1.07]}\end{array}$ & 4 & $\begin{array}{c}0.02 \\
{[-0.26,0.61]}\end{array}$ & 0.661 & 0.214 \\
\hline $\mathrm{AR}(1)$ with time trend & $\begin{array}{c}-822.26 \\
(-0.36)\end{array}$ & $\begin{array}{c}-1161.2 \\
(-95.71)\end{array}$ & $\begin{array}{c}0.97 \\
{[0.46,1.30]}\end{array}$ & 14 & $\begin{array}{c}-0.06 \\
{[-0.37,0.39]}\end{array}$ & 0.377 & --- \\
\hline AR(1) with an intercept* & $\begin{array}{c}\text { 6254.27 } \\
(7.21) \\
\end{array}$ & --- & $\begin{array}{c}1.49 \\
{[0.97,1.90]} \\
\end{array}$ & 5 & $\begin{array}{c}0.08 \\
{[-0.15,0.44]} \\
\end{array}$ & $\mathbf{0 . 0 8 0}$ & --- \\
\hline AR(1) with no regressors & --- & --- & 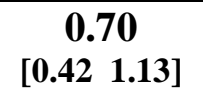 & 5 & $\begin{array}{c}-\mathbf{0 . 0 9} \\
{[-0.37,0.33]}\end{array}$ & 0.403 & --- \\
\hline White noise with trend & $\begin{array}{c}9.3278 \\
(0.241)\end{array}$ & $\begin{array}{c}-1375.5 \\
(-71.72)\end{array}$ & $\begin{array}{c}1.06 \\
{[0.79,1.42]}\end{array}$ & 5 & $\begin{array}{c}0.37 \\
{[0.02,0.83]}\end{array}$ & --- & --- \\
\hline White noise + intercept & $\begin{array}{c}7126.64 \\
(7.138)\end{array}$ & --- & $\begin{array}{c}1.51 \\
{[1.07,1.87]}\end{array}$ & 6 & $\begin{array}{c}0.10 \\
{[-0.22,0.43]}\end{array}$ & --- & --- \\
\hline White noise with no reg. & --- & --- & $\begin{array}{c}0.90 \\
{[0.74,1.34]}\end{array}$ & 6 & $\begin{array}{c}0.13 \\
{[-0.16,0.29]}\end{array}$ & --- & --- \\
\hline
\end{tabular}

In bold, the models for which the null hypothesis of white noise errors cannot be rejected. “***”" indicates the best model specification using LR tests and other likelihood criteria. 
Table 2: Coefficient estimates with one fractional structure

\section{2a) Series: Dividends}

\begin{tabular}{|c|c|c|c|c|c|}
\hline & $\alpha$ & $\beta$ & $\mathrm{d}_{1}$ & $\rho_{1}$ & $\rho_{2}$ \\
\hline $\operatorname{AR}(2)$ with time trend & $\begin{array}{l}0.024 \\
(0.338)\end{array}$ & $\begin{array}{l}0.005 \\
(0.022)\end{array}$ & $\begin{array}{c}0.955 \\
{[0.797,1.404]}\end{array}$ & 0.394 & -0.025 \\
\hline $\operatorname{AR}(2)$ with an intercept & $\begin{array}{c}0.031 \\
(1.110)\end{array}$ & --- & $\begin{array}{c}0.955 \\
{[0.796,1.402]}\end{array}$ & 0.395 & -0.025 \\
\hline $\operatorname{AR}(2)$ with no regressors*** & --- & --- & $\begin{array}{c}0.955 \\
{[0.801,1.403]} \\
\end{array}$ & 0.395 & -0.025 \\
\hline $\mathrm{AR}(1)$ with time trend & $\begin{array}{l}0.046 \\
(0.062)\end{array}$ & $\begin{array}{l}0.159 \\
(3.385)\end{array}$ & $\begin{array}{c}0^{\prime} .937 \\
{[0.817,1.101]}\end{array}$ & 0.401 & --- \\
\hline AR(1) with an intercept & $\begin{array}{l}0.283 \\
(0.384)\end{array}$ & --- & $\begin{array}{c}0.939 \\
{[0.796,1.087]}\end{array}$ & 0.404 & --- \\
\hline AR(1) with no regressors & --- & --- & $\begin{array}{c}0.944 \\
{[0.787,1.080]}\end{array}$ & 0.397 & --- \\
\hline White noise with trend & $\begin{array}{l}0.1697 \\
(0.251)\end{array}$ & $\begin{array}{l}0.1447 \\
(0.878)\end{array}$ & $\begin{array}{c}1.232 \\
{[1.101,1.440]}\end{array}$ & --- & --- \\
\hline White noise + intercept & $\begin{array}{r}0.2467 \\
(1.367)\end{array}$ & --- & $\begin{array}{c}1.221 \\
{[1,094,1.435]}\end{array}$ & --- & --- \\
\hline White noise with no reg. & --- & --- & $\begin{array}{c}1.217 \\
{[1.091,1.433]}\end{array}$ & --- & --- \\
\hline
\end{tabular}

2b) Series: Earnings

\begin{tabular}{|c|c|c|c|c|c|}
\hline & $\alpha$ & $\beta$ & $\mathrm{d}_{1}$ & $\rho_{1}$ & $\rho_{2}$ \\
\hline $\operatorname{AR}(2)$ with time trend $* * *$ & $\begin{array}{l}-0.911 \\
(0.115) \\
\end{array}$ & $\begin{array}{r}0.048 \\
(0.091)\end{array}$ & $\begin{array}{c}0.872 \\
{[0.744,1.101]}\end{array}$ & 0.250 & -0.585 \\
\hline $\operatorname{AR}(2)$ with an intercept & $\begin{array}{l}-0.801 \\
(0.094)\end{array}$ & --- & $\begin{array}{c}0.879 \\
{[0.765,1.098]}\end{array}$ & 0.251 & -0.584 \\
\hline $\operatorname{AR}(2)$ with no regressors & --- & --- & $\begin{array}{c}0.879 \\
{[0.766 \quad 1.098]}\end{array}$ & 0.255 & -0.583 \\
\hline $\mathrm{AR}(1)$ with time trend & $\begin{array}{l}-3.597 \\
(-0.741)\end{array}$ & $\begin{array}{l}0.351 \\
(4.122)\end{array}$ & $\begin{array}{c}0.588 \\
{[0.513,0.682]}\end{array}$ & 0.304 & --- \\
\hline AR(1) with an intercept & $\begin{array}{l}4.480 \\
(1.034)\end{array}$ & --- & $\begin{array}{c}0.566 \\
{[0.480,0.633]}\end{array}$ & 0.372 & --- \\
\hline AR(1) with no regressors & --- & --- & $\begin{array}{c}0.548 \\
{[0.471,0.661]}\end{array}$ & 0.381 & --- \\
\hline White noise with trend & $\begin{array}{c}-1.2251 \\
(-0.220)\end{array}$ & $\begin{array}{l}0.4136 \\
(2.392)\end{array}$ & $\begin{array}{c}0.765 \\
{[0.654,1.001]}\end{array}$ & --- & --- \\
\hline White noise + intercept & $\begin{array}{l}1.1841 \\
(0.217)\end{array}$ & --- & $\begin{array}{c}0.767 \\
{[0.661,0.994]}\end{array}$ & --- & --- \\
\hline White noise with no reg. & --- & --- & $\begin{array}{c}0.772 \\
{[0.668,0.999]}\end{array}$ & --- & --- \\
\hline
\end{tabular}

(continued) 


\begin{tabular}{|c|c|c|c|c|c|}
\hline \multicolumn{6}{|c|}{ 2c) Series: Interest rates } \\
\hline & $\alpha$ & $\beta$ & $\mathrm{d}_{1}$ & $\rho_{1}$ & $\rho_{2}$ \\
\hline $\operatorname{AR}(2)$ with time trend & $\begin{array}{l}6.287 \\
(4.221)\end{array}$ & $\begin{array}{l}-0.054 \\
(-1.349)\end{array}$ & $\begin{array}{c}0.702 \\
{[0.487,1.064]}\end{array}$ & 0.154 & -0.139 \\
\hline$A R(2)$ with an intercept & $\begin{array}{l}4.666 \\
(4.675)\end{array}$ & --- & $\begin{array}{c}0.590 \\
{[0.431,1.064]} \\
\end{array}$ & 0.270 & -0.102 \\
\hline $\operatorname{AR}(2)$ with no regressors $* * *$ & --- & --- & $\begin{array}{c}0.702 \\
{[0.337,1.064]}\end{array}$ & 0.318 & -0.053 \\
\hline $\operatorname{AR}(1)$ with time trend & $\begin{array}{l}6.202 \\
(5.057)\end{array}$ & $\begin{array}{l}-0.017 \\
(-0.903)\end{array}$ & $\begin{array}{c}0.555 \\
{[0.384,0.762]}\end{array}$ & 0.273 & -- \\
\hline AR(1) with an intercept & $\begin{array}{l}5.488 \\
(5.590)\end{array}$ & --- & $\begin{array}{c}0.495 \\
{[0.371,0.750]}\end{array}$ & 0.338 & --- \\
\hline AR(1) with no regressors & -- & --- & $\begin{array}{c}0.535 \\
{[0.405,0.622]}\end{array}$ & 0.314 & --- \\
\hline White noise with trend & $\begin{array}{l}6.495 \\
(4.471)\end{array}$ & $\begin{array}{c}-0.0269 \\
(-0.630)\end{array}$ & $\begin{array}{c}0.751 \\
{[0.639,0.913]}\end{array}$ & --- & --- \\
\hline White noise + intercept & $\begin{array}{c}6.3089 \\
(4.445)\end{array}$ & --- & $\begin{array}{c}0.746 \\
{[0.631,0.912]}\end{array}$ & --- & --- \\
\hline White noise with no reg. & --- & --- & $\begin{array}{c}0.745 \\
{[0.622,0.926]}\end{array}$ & --- & --- \\
\hline \multicolumn{6}{|c|}{ 2d) Series: Government bond yields } \\
\hline & $\alpha$ & $\beta$ & $\mathrm{d}_{1}$ & $\rho_{1}$ & $\rho_{2}$ \\
\hline $\operatorname{AR}(2)$ with time trend & $\begin{array}{l}5.345 \\
(8.030)\end{array}$ & $\begin{array}{l}-0.036 \\
(-0.541)\end{array}$ & $\begin{array}{c}1.058 \\
{[0.793,1.382]}\end{array}$ & -0.265 & -0.068 \\
\hline $\mathbf{A R}(2)$ with an intercept & $\begin{array}{l}5.317 \\
(7.134)\end{array}$ & --- & $\begin{array}{c}1.059 \\
{[0.793,1.383]}\end{array}$ & -0.257 & -0.077 \\
\hline $\operatorname{AR}(2)$ with no regressors & --- & --- & $\begin{array}{c}1.056 \\
{[0.796,1.399]}\end{array}$ & -0.256 & -0.036 \\
\hline $\operatorname{AR}(1)$ with time trend & $\begin{array}{l}5.332 \\
(6.936)\end{array}$ & $\begin{array}{l}-0.013 \\
(-0.213)\end{array}$ & $\begin{array}{c}0.992 \\
{[0.645,1.239]}\end{array}$ & -0.184 & --- \\
\hline AR(1) with an intercept & $\begin{array}{l}5.318 \\
(6.943)\end{array}$ & --- & $\begin{array}{c}0.992 \\
{[0.852,1.155]}\end{array}$ & -0.184 & -- \\
\hline $\operatorname{AR}(1)$ with no regressors $* * *$ & --- & --- & $\begin{array}{c}0.892 \\
{[0.775,1.239]}\end{array}$ & -0.183 & --- \\
\hline White noise with trend & $\begin{array}{l}5.292 \\
(7.042)\end{array}$ & $\begin{array}{c}-0.0078 \\
(-0.212)\end{array}$ & $\begin{array}{c}0.877 \\
{[0.798,0.982]}\end{array}$ & --- & --- \\
\hline White noise + intercept & $\begin{array}{l}5.274 \\
(7.064)\end{array}$ & --- & $\begin{array}{c}0.877 \\
{[0.797,0.982]}\end{array}$ & -- & -- \\
\hline White noise with no reg. & --- & --- & $\begin{array}{c}0.862 \\
{[0.766,0.988]}\end{array}$ & --- & -- \\
\hline
\end{tabular}

(continued) 


\begin{tabular}{|c|c|c|c|c|c|}
\hline \multicolumn{6}{|c|}{ 2e) Series: S\&P composite stock price index } \\
\hline & $\alpha$ & $\beta$ & $\mathrm{d}_{1}$ & $\rho_{1}$ & $\rho_{2}$ \\
\hline $\operatorname{AR}(2)$ with time trend & $\begin{array}{c}-11.607 \\
(5.441)\end{array}$ & $\begin{array}{c}0.553 \\
(-0.117)\end{array}$ & $\begin{array}{c}0.926 \\
{[0.698,1.169]}\end{array}$ & 0.147 & -0.120 \\
\hline $\operatorname{AR}(2)$ with an intercept $* * *$ & $\begin{array}{c}-10.713 \\
(-4,198) \\
\end{array}$ & --- & $\begin{array}{c}0.926 \\
{[0.698,1.171]} \\
\end{array}$ & 0.147 & $-\mathbf{0 . 1 2 0}$ \\
\hline $\operatorname{AR}(2)$ with no regressors & --- & --- & $\begin{array}{c}0.924 \\
{[0.722,1.171]} \\
\end{array}$ & 0.150 & $-\mathbf{0 . 1 1 9}$ \\
\hline $\mathrm{AR}(1)$ with time trend & $\begin{array}{c}-14.746 \\
(-0.192)\end{array}$ & $\begin{array}{l}8.098 \\
(2.495)\end{array}$ & $\begin{array}{c}0.843 \\
{[0.732,0.991]}\end{array}$ & 0.210 & --- \\
\hline AR(1) with an intercept & $\begin{array}{r}10.039 \\
(\mathbf{0 . 1 3 2}) \\
\end{array}$ & --- & \begin{tabular}{c|}
0.846 \\
{$[0.696,0.989]$} \\
\end{tabular} & 0.214 & --- \\
\hline $\operatorname{AR}(1)$ with no regressors & --- & --- & $\begin{array}{c}0.849 \\
{[0.731,0.990]}\end{array}$ & 0.210 & --- \\
\hline White noise with trend & $\begin{array}{l}-5.384 \\
(-0.069)\end{array}$ & $\begin{array}{l}8.731 \\
(1.515)\end{array}$ & $\begin{array}{c}0.974 \\
{[0.877,1.125]}\end{array}$ & --- & --- \\
\hline White noise + intercept & $\begin{array}{l}\mathbf{4 . 7 8 6} \\
(\mathbf{0 . 0 6 2})\end{array}$ & --- & $\begin{array}{c}0.974 \\
{[0.882,1.121]} \\
\end{array}$ & -- & -- \\
\hline White noise with no reg. & --- & --- & $\begin{array}{c}0.975 \\
{[0.883,1.122]}\end{array}$ & -- & -- \\
\hline
\end{tabular}

In bold, the models for which the null hypothesis of white noise errors cannot be rejected. "***”" indicates the best model specification using LR tests and other likelihood criteria. 
Table 3: Selected break-date for each series

\begin{tabular}{|c|c|c|c|c|}
\hline & Bai (1997) & Z \& A (1992) & L \& S (2001) & G-A (2008) \\
\hline Dividends & 1976 & 1968 & $1968 \& 1972$ & $1976-1977$ \\
\hline Earnings & 1973 & 1972 & $1972-1974$ & $1973-1975$ \\
\hline Interest Rate & 1973 & $1965 \& 1973$ & 1973 & $1973-1974$ \\
\hline Bond Yields & 1979 & $1965 \& 1973$ & $1973-1981$ & $1970-1073$ \\
\hline Stock prices & 1973 & 1974 & $1973 \& 1974$ & 1973 \\
\hline
\end{tabular}

Z \& A stands for Zivot and Andrews (1992), L \& S for Lee and Strazicich (2001) and G-A for Gil-Alana (2008). 
Table 4: Estimates in the nonlinear case with two fractional structures

\begin{tabular}{|c|c|c|c|c|c|c|c|c|}
\hline \multicolumn{9}{|c|}{ 4a) Series: Dividends } \\
\hline & $\alpha_{1}$ & $\alpha_{2}$ & $\beta_{2}$ & $\mathrm{~d}_{1}$ & $\mathrm{r}$ & $\mathrm{d}_{2}$ & $\rho_{1}$ & $\rho_{2}$ \\
\hline $\mathrm{AR}(2)$ & $\begin{array}{c}-114.85 \\
(-2.167)\end{array}$ & $\begin{array}{c}-297.26 \\
(-0.432)\end{array}$ & $\begin{array}{l}7.001 \\
(0.004)\end{array}$ & $\begin{array}{c}1.25 \\
{[0.91,1.83]}\end{array}$ & 7 & $\begin{array}{c}0.55 \\
{[0.14,1.19]}\end{array}$ & -0.616 & -0.184 \\
\hline $\operatorname{AR}(1) * * *$ & $\begin{array}{c}-91.289 \\
(-7.774)\end{array}$ & $\begin{array}{l}-51.396 \\
(-10.078)\end{array}$ & $\begin{array}{l}-1.375 \\
(-2.014)\end{array}$ & $\begin{array}{c}1.05 \\
{[0.88,1.51]}\end{array}$ & 11 & $\begin{array}{c}0.44 \\
{[0.27,0.64]}\end{array}$ & -0.076 & -- \\
\hline White Noise & $\begin{array}{c}-584.60 \\
(-61.54)\end{array}$ & $\begin{array}{c}-66.491 \\
(-.344)\end{array}$ & $\begin{array}{c}-14.036 \\
(-1.992)\end{array}$ & $\begin{array}{c}0.07 \\
{[0.01,0.11]}\end{array}$ & 13 & $\begin{array}{c}1.08 \\
{[1.02, \quad 1.17]}\end{array}$ & --- & --- \\
\hline \multicolumn{9}{|c|}{ 4b) Series: Earnings } \\
\hline & $\alpha_{1}$ & $\alpha_{2}$ & $\beta_{2}$ & $\mathrm{~d}_{1}$ & r & $\mathrm{d}_{2}$ & $\rho_{1}$ & $\rho_{2}$ \\
\hline $\operatorname{AR}(2) * * *$ & $\begin{array}{c}-262.18 \\
(-4.53)\end{array}$ & $\begin{array}{c}-198.18 \\
(-12.43)\end{array}$ & $\begin{array}{l}-4.360 \\
(--3.77)\end{array}$ & $\begin{array}{c}1.24 \\
{[1.09,1.51]}\end{array}$ & 7 & $\begin{array}{c}0.66 \\
{[0.32,0.81]}\end{array}$ & 0.251 & -0.255 \\
\hline $\operatorname{AR}(1)$ & $\begin{array}{c}-305.31 \\
(-14.44)\end{array}$ & $\begin{array}{l}312.05 \\
(14.04)\end{array}$ & $\begin{array}{c}-15.847 \\
(-1.181)\end{array}$ & $\begin{array}{c}0.30 \\
{[0.02,0.67]}\end{array}$ & 15 & $\begin{array}{c}1.33 \\
{[1.23,1.54]}\end{array}$ & -0.148 & --- \\
\hline White Noise & $\begin{array}{c}-1101.33 \\
(-64.54)\end{array}$ & $\begin{array}{c}452.05 \\
(16.18)\end{array}$ & $\begin{array}{c}-40.617 \\
(-0.553)\end{array}$ & $\begin{array}{c}0.03 \\
{[-.27,0.52]}\end{array}$ & 7 & $\begin{array}{c}1.39 \\
{[1.22,1.54]}\end{array}$ & --- & --- \\
\hline \multicolumn{9}{|c|}{ 4c) Series: Interest rates } \\
\hline & $\alpha_{1}$ & $\alpha_{2}$ & $\beta_{2}$ & $\mathrm{~d}_{1}$ & $\mathrm{r}$ & $\mathrm{d}_{2}$ & $\rho_{1}$ & $\rho_{2}$ \\
\hline $\operatorname{AR}(2)$ & $\begin{array}{l}22.396 \\
(3.433)\end{array}$ & $\begin{array}{l}169.83 \\
(0.009)\end{array}$ & $\begin{array}{l}-3.035 \\
(0.041)\end{array}$ & $\begin{array}{c}1.22 \\
{[0.98,1.54]}\end{array}$ & 5 & $\begin{array}{c}0.56 \\
{[0.33,0.86]}\end{array}$ & -0.543 & 0.016 \\
\hline $\operatorname{AR}(1) * * *$ & $\begin{array}{c}-\mathbf{- 8 2 . 9 5 2} \\
(-9.558)\end{array}$ & $\begin{array}{c}-113.64 \\
(-8.89)\end{array}$ & $\begin{array}{l}-5.173 \\
(-2.32)\end{array}$ & $\begin{array}{c}0.32 \\
{[0.15,0.49]}\end{array}$ & 15 & $\begin{array}{c}1.29 \\
{[1.18,1.46]}\end{array}$ & -0.251 & --- \\
\hline White Noise & $\begin{array}{c}10.115 \\
(2.13)\end{array}$ & $\begin{array}{c}60.603 \\
(3.36)\end{array}$ & $\begin{array}{l}-61.708 \\
(-4.448)\end{array}$ & $\begin{array}{c}0.84 \\
{[0.77,1.09]}\end{array}$ & 3 & $\begin{array}{c}-0.11 \\
{[-0.56, \quad 0.33]}\end{array}$ & --- & --- \\
\hline \multicolumn{9}{|c|}{ 4d) Series: Government bond yields } \\
\hline & & $\alpha_{1}$ & $\alpha_{2}$ & $\mathrm{~d}_{1}$ & $\mathrm{r}$ & $\mathrm{d}_{2}$ & $\rho_{1}$ & $\rho_{2}$ \\
\hline $\mathrm{AF}$ & & $\begin{array}{l}-3.287 \\
(-2.89)\end{array}$ & $\begin{array}{l}-4.006 \\
(-2.095)\end{array}$ & $\begin{array}{c}0.97 \\
{[0.68,1.22]}\end{array}$ & 13 & $\begin{array}{c}0.77 \\
{[0.49,1.23]}\end{array}$ & 0.931 & -0.377 \\
\hline $\mathbf{A R}($ & $* * *$ & $\begin{array}{c}-26.576 \\
(-4.15)\end{array}$ & $\begin{array}{c}-33.123 \\
(-4.55)\end{array}$ & $\begin{array}{c}0.96 \\
{[0.82,1.05]}\end{array}$ & 3 & $\begin{array}{c}0.17 \\
{[0.04,0.50]}\end{array}$ & -0.109 & --- \\
\hline White & Toise & $\begin{array}{c}-34.841 \\
(-6.711)\end{array}$ & $\begin{array}{c}-36.915 \\
(-6.691)\end{array}$ & $\begin{array}{c}0.91 \\
{[0.82,1.12]}\end{array}$ & 8 & $\begin{array}{c}0.21 \\
{[0.04, \quad 0.55]}\end{array}$ & --- & --- \\
\hline \multicolumn{9}{|c|}{ 4e) Series: Stock price index } \\
\hline & $\alpha_{1}$ & $\alpha_{2}$ & $\beta_{2}$ & $\mathrm{~d}_{1}$ & $\mathrm{r}$ & $\mathrm{d}_{2}$ & $\rho_{1}$ & $\rho_{2}$ \\
\hline $\operatorname{AR}(2)$ & $\begin{array}{c}121.055 \\
(4.21)\end{array}$ & $\begin{array}{c}1373.73 \\
(2.13)\end{array}$ & $\begin{array}{c}-29.690 \\
(-1.56)\end{array}$ & $\begin{array}{c}1.31 \\
{[1.02,1.59]}\end{array}$ & 6 & $\begin{array}{c}0.51 \\
{[0.23,0.69]}\end{array}$ & -0.833 & 0.379 \\
\hline $\operatorname{AR}(1) * * *$ & $\begin{array}{c}-9387.07 \\
(-19.74)\end{array}$ & $\begin{array}{c}-2273.1 \\
(-14.45)\end{array}$ & $\begin{array}{c}-163.84 \\
(-4.51)\end{array}$ & $\begin{array}{c}1.04 \\
{[0.65,1.55]}\end{array}$ & 15 & $\begin{array}{c}0.40 \\
{[0.14,0.97]}\end{array}$ & 0.091 & --- \\
\hline White Noise & $\begin{array}{c}7506.88 \\
(7.32) \\
\end{array}$ & $\begin{array}{c}-6298.6 \\
(-4.55) \\
\end{array}$ & $\begin{array}{c}-319.42 \\
(-3.54) \\
\end{array}$ & $\begin{array}{c}1.41 \\
{[0.79,1.88]} \\
\end{array}$ & 7 & $\begin{array}{c}-0.02 \\
{[-0.09,0.15]}\end{array}$ & --- & --- \\
\hline
\end{tabular}

In bold, the models for which the null hypothesis of white noise errors cannot be rejected. “***” indicates the best model specification using LR tests and other likelihood criteria. 
Table 5: Coefficient estimates with one fractional structure

5a) Series: Dividends

\begin{tabular}{|l|c|c|c|c|c|c|} 
& $\alpha_{1}$ & $\alpha_{2}$ & $\beta_{2}$ & $\mathrm{~d}_{1}$ & $\rho_{1}$ & $\rho_{2}$ \\
\hline $\mathrm{AR}(2)$ & $\begin{array}{c}0.4704 \\
(-0.55)\end{array}$ & $\begin{array}{c}-0.2074 \\
(-0.16)\end{array}$ & $\begin{array}{c}0.8458 \\
(1.23)\end{array}$ & $\begin{array}{c}0.74 \\
{[0.61,0.86]}\end{array}$ & 0.550 & -0.167 \\
\hline AR(1)*** & $\begin{array}{c}\mathbf{0 . 4 8 8 5} \\
\mathbf{( 1 . 5 6 )}\end{array}$ & $\begin{array}{c}\mathbf{- 0 . 2 1 3 0} \\
\mathbf{( - 2 . 1 7 )}\end{array}$ & $\begin{array}{c}\mathbf{0 . 8 6 5 2} \\
\mathbf{( 1 2 . 6 6 )}\end{array}$ & $\begin{array}{c}\mathbf{0 . 7 3} \\
{[\mathbf{0 . 6 4}, \mathbf{0 . 8 9}]}\end{array}$ & $\mathbf{0 . 5 1 3}$ & -- \\
\hline White noise & $\begin{array}{c}0.3210 \\
(0.42)\end{array}$ & $\begin{array}{c}0.0217 \\
(0.19)\end{array}$ & $\begin{array}{c}0.6157 \\
(3.53)\end{array}$ & $\begin{array}{c}1.10 \\
{[0.85,1.39]}\end{array}$ & --- & -- \\
\hline
\end{tabular}

5b) Series: Earnings

\begin{tabular}{|l|c|c|c|c|c|c|}
\hline & $\alpha_{1}$ & $\alpha_{2}$ & $\beta_{2}$ & $\mathrm{~d}_{1}$ & $\rho_{1}$ & $\rho_{2}$ \\
\hline AR(2)*** & $\begin{array}{c}\mathbf{0 . 7 1 0 4} \\
(\mathbf{0 . 1 1})\end{array}$ & $\begin{array}{c}\mathbf{- 0 . 6 6 1 6} \\
\mathbf{( - 0 . 0 8}\end{array}$ & $\begin{array}{c}\mathbf{2 . 5 3 3 2} \\
\mathbf{( 5 . 2 1 )}\end{array}$ & $\begin{array}{c}\mathbf{1 . 0 2} \\
{[\mathbf{0 . 8 0 , 1 . 3 3}}\end{array}$ & $\mathbf{0 . 3 1 4}$ & $\mathbf{- 0 . 5 4 0}$ \\
\hline AR(1) & $\begin{array}{c}1.0743 \\
(0.16)\end{array}$ & $\begin{array}{c}-1.4158 \\
(-0.14)\end{array}$ & $\begin{array}{c}3.1548 \\
(6.90)\end{array}$ & $\begin{array}{c}0.63 \\
{[0.49,0.80]}\end{array}$ & 0.325 & -- \\
\hline White noise & $\begin{array}{c}0.8003 \\
(0.12)\end{array}$ & $\begin{array}{c}-0.8748 \\
(-0.09)\end{array}$ & $\begin{array}{c}2.6979 \\
(5.77)\end{array}$ & $\begin{array}{c}0.69 \\
{[0.55,0.86]}\end{array}$ & --- & -- \\
\hline
\end{tabular}

5c) Series: Interest rate

\begin{tabular}{|c|c|c|c|c|c|c|}
\hline & $\alpha_{1}$ & $\alpha_{2}$ & $\beta_{2}$ & $\mathrm{~d}_{1}$ & $\rho_{1}$ & $\rho_{2}$ \\
\hline $\operatorname{AR}(2) * * *$ & $\begin{array}{c}12.6989 \\
(6.52)\end{array}$ & $\begin{array}{c}21.2274 \\
(7.44)\end{array}$ & $\begin{array}{c}\mathbf{- 0 . 4 2 3 7} \\
\mathbf{( - 3 . 4 6 )}\end{array}$ & $\begin{array}{c}0.66 \\
{[0.40,1.23]}\end{array}$ & 0.228 & -0.074 \\
\hline $\operatorname{AR}(\mathbf{1})$ & $\begin{array}{c}10.411 \\
(4.41)\end{array}$ & $\begin{array}{c}19.7797 \\
(5.59)\end{array}$ & $\begin{array}{c}\mathbf{- 0 . 6 7 7 8} \\
(-3.99)\end{array}$ & $\begin{array}{c}0.59 \\
{[0.31,0.75]}\end{array}$ & 0.247 & --- \\
\hline White noise & $\begin{array}{c}9.6139 \\
(5.64)\end{array}$ & $\begin{array}{c}15.5416 \\
(6.27)\end{array}$ & $\begin{array}{c}-0.3054 \\
(-2.43)\end{array}$ & $\begin{array}{c}0.71 \\
{[0.53,0.87]}\end{array}$ & - & -- \\
\hline
\end{tabular}

5d) Series: Government bond yield

\begin{tabular}{|c|c|c|c|c|c|}
\hline & $\alpha_{1}$ & $\alpha_{2}$ & $\mathrm{~d}_{1}$ & $\rho_{1}$ & $\rho_{2}$ \\
\hline $\operatorname{AR}(2)^{* * *}$ & $\begin{array}{l}5.344 \\
(7.22)\end{array}$ & $\begin{array}{l}4.614 \\
(4.45)\end{array}$ & $\begin{array}{c}0.97 \\
{[0.81,1.32]}\end{array}$ & -0.156 & -0.002 \\
\hline $\mathbf{A R}(1)$ & $\begin{array}{l}5.702 \\
(8-71)\end{array}$ & $\begin{array}{l}5.801 \\
(5.90)\end{array}$ & $\begin{array}{c}0.98 \\
{[0.80,1.27]}\end{array}$ & -0.155 & --- \\
\hline White noise & $\begin{array}{l}6.003 \\
(6.80)\end{array}$ & $\begin{array}{l}5.902 \\
(4.505)\end{array}$ & $\begin{array}{c}0.90 \\
{[0.81,1.04]}\end{array}$ & --- & --- \\
\hline
\end{tabular}

5e) Series: Stock price index

\begin{tabular}{|c|c|c|c|c|c|c|}
\hline & $\alpha_{1}$ & $\alpha_{2}$ & $\beta_{2}$ & $\mathrm{~d}_{1}$ & $\rho_{1}$ & $\rho_{2}$ \\
\hline $\operatorname{AR}(2) * * *$ & $\begin{array}{c}10.0391 \\
(0.10)\end{array}$ & $\begin{array}{c}-101.490 \\
(-0.75)\end{array}$ & $\begin{array}{c}55.9646 \\
(8,82)\end{array}$ & $\begin{array}{c}0.67 \\
{[0.53,0.81]}\end{array}$ & 0.109 & -0.752 \\
\hline $\mathbf{A R}(1)$ & $\begin{array}{c}24.848 \\
(0.82)\end{array}$ & $\begin{array}{c}227.639 \\
(3.26)\end{array}$ & $\begin{array}{c}51.0496 \\
(-17.92)\end{array}$ & $\begin{array}{c}0.19 \\
{[-0.17,0.44]}\end{array}$ & 0.744 & --- \\
\hline White noise & $\begin{array}{c}\mathbf{6 . 0 0 7 9} \\
(0.07)\end{array}$ & $\begin{array}{c}-\mathbf{3 5 . 9 7 2 7} \\
(-\mathbf{0 . 3 0})\end{array}$ & $\begin{array}{c}39.3996 \\
(4.80)\end{array}$ & $\begin{array}{c}0.84 \\
{[0.63,1.15]}\end{array}$ & --- & -- \\
\hline
\end{tabular}

In bold, the models for which the null hypothesis of white noise errors cannot be rejected. "***" indicates the best model specification using LR tests and other likelihood criteria. 
Figure 2: Recursive estimates of the differencing parameters for dividends

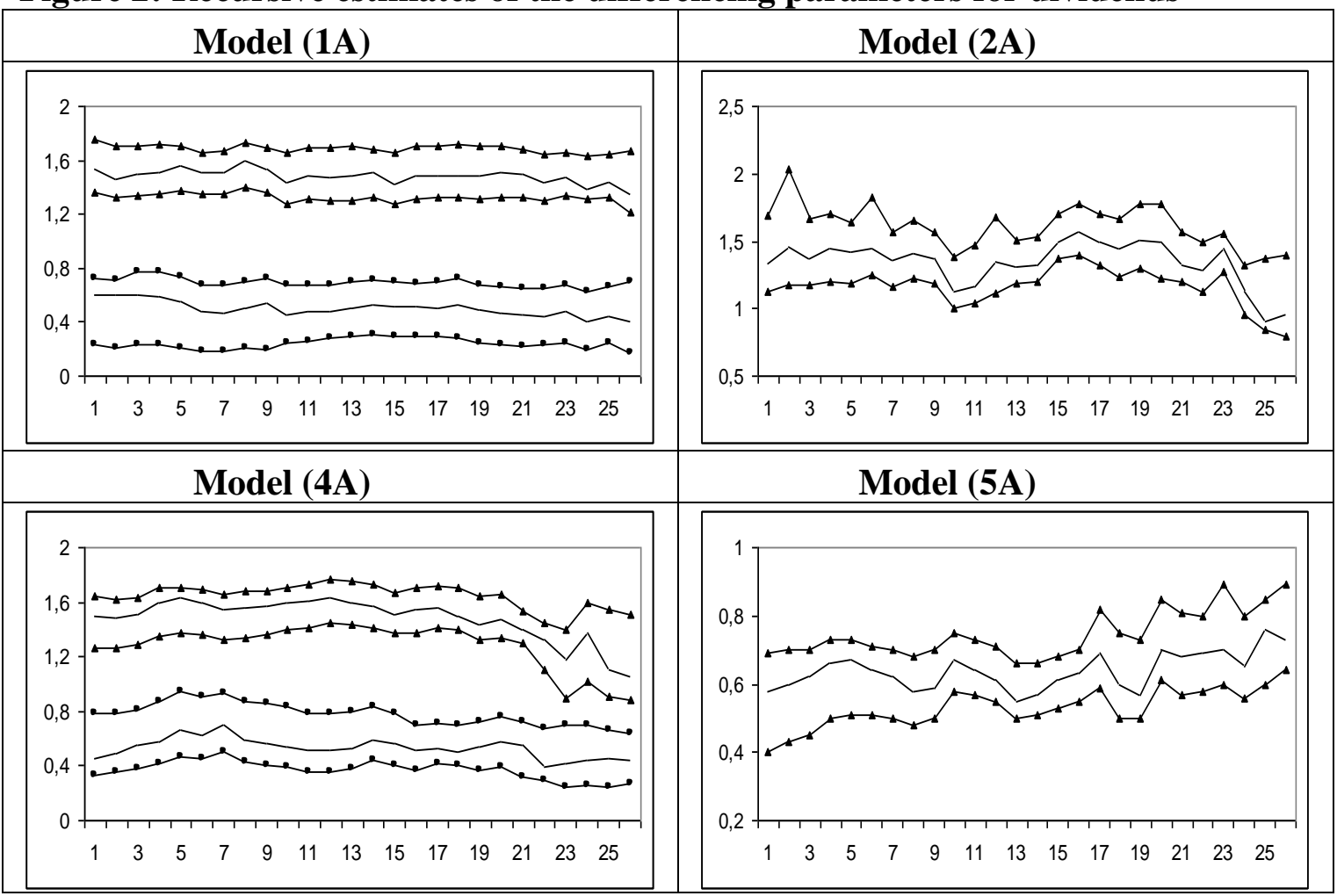

The thin lines refer to the estimates of the fractional differencing parameters, the top one is $\mathrm{d}_{1}$, and the bottom one, $d_{2}$. The $95 \%$ confidence bands are also displayed.

Figure 3: Recursive estimates of the differencing parameters for earnings

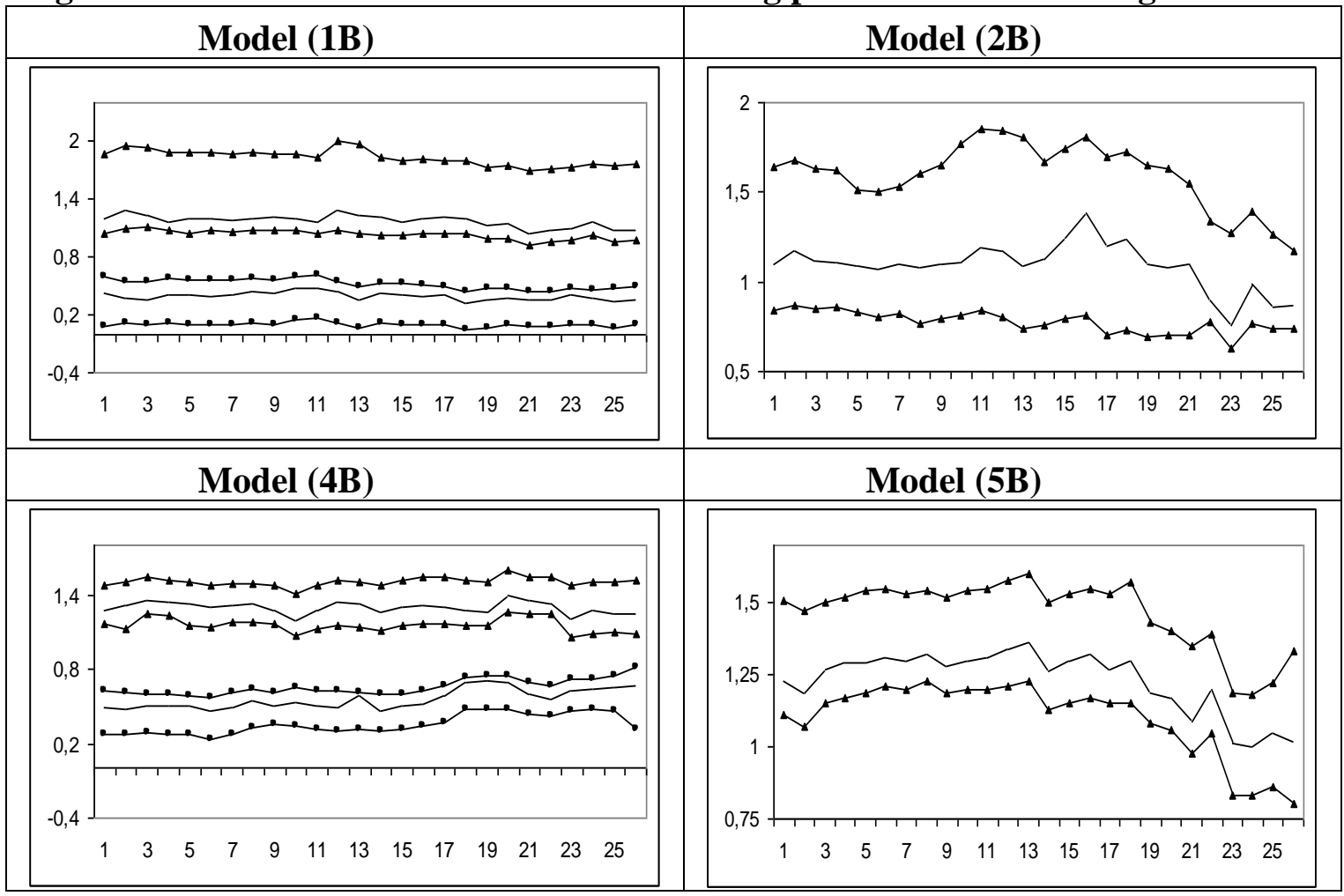

The thin lines refer to the estimates of the fractional differencing parameters, the top one is $\mathrm{d}_{1}$, and the bottom one, $\mathrm{d}_{2}$. The $95 \%$ confidence bands are also displayed. 
Figure 4: Recursive estimates of the differencing parameters for interest rates

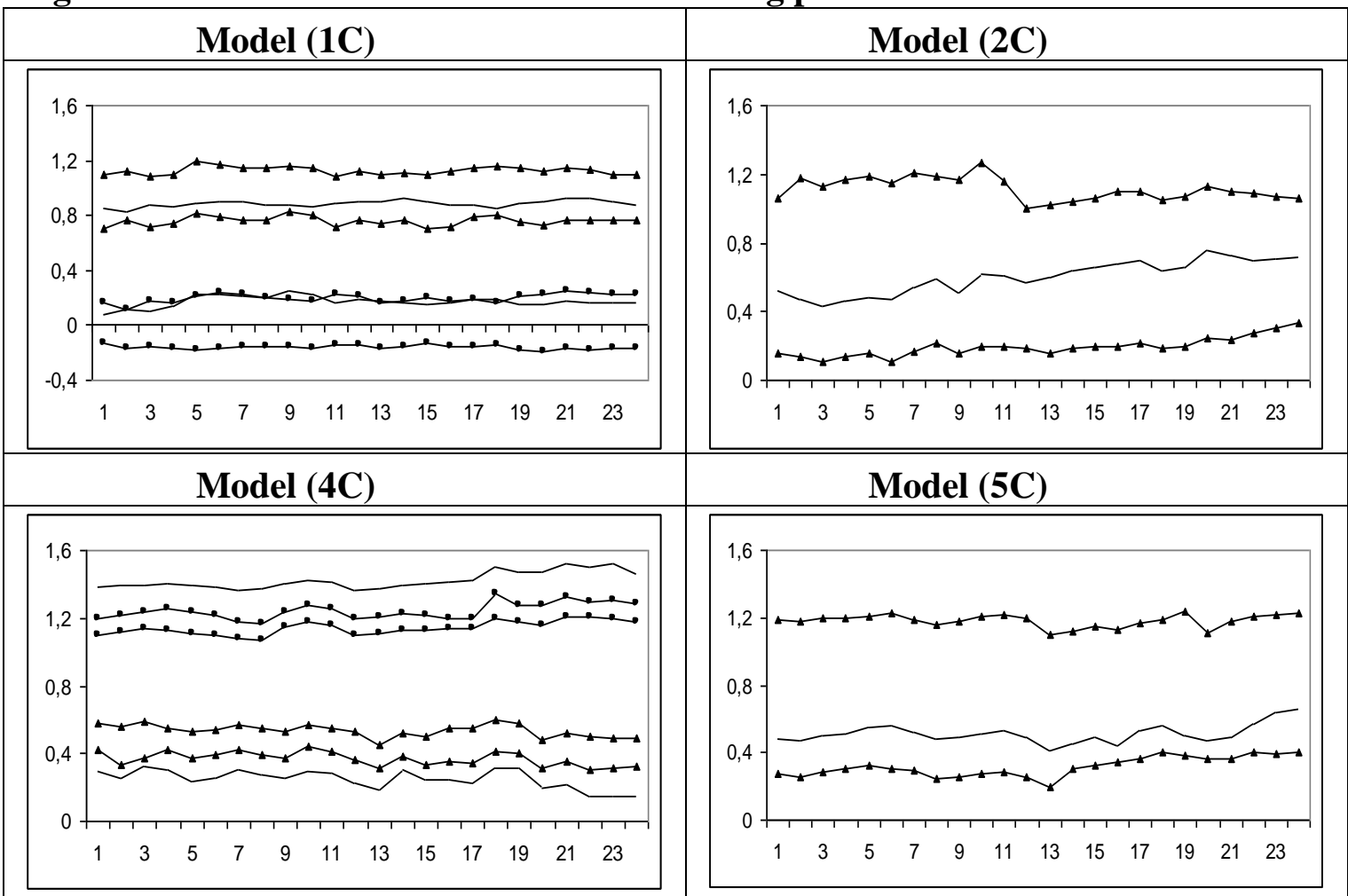

The thin lines refer to the estimates of the fractional differencing parameters, the top one is $\mathrm{d}_{1}$, and the bottom one, $d_{2}$. The $95 \%$ confidence bands are also displayed.

Figure 5: Recursive estimates of the differencing parameters for bond yields

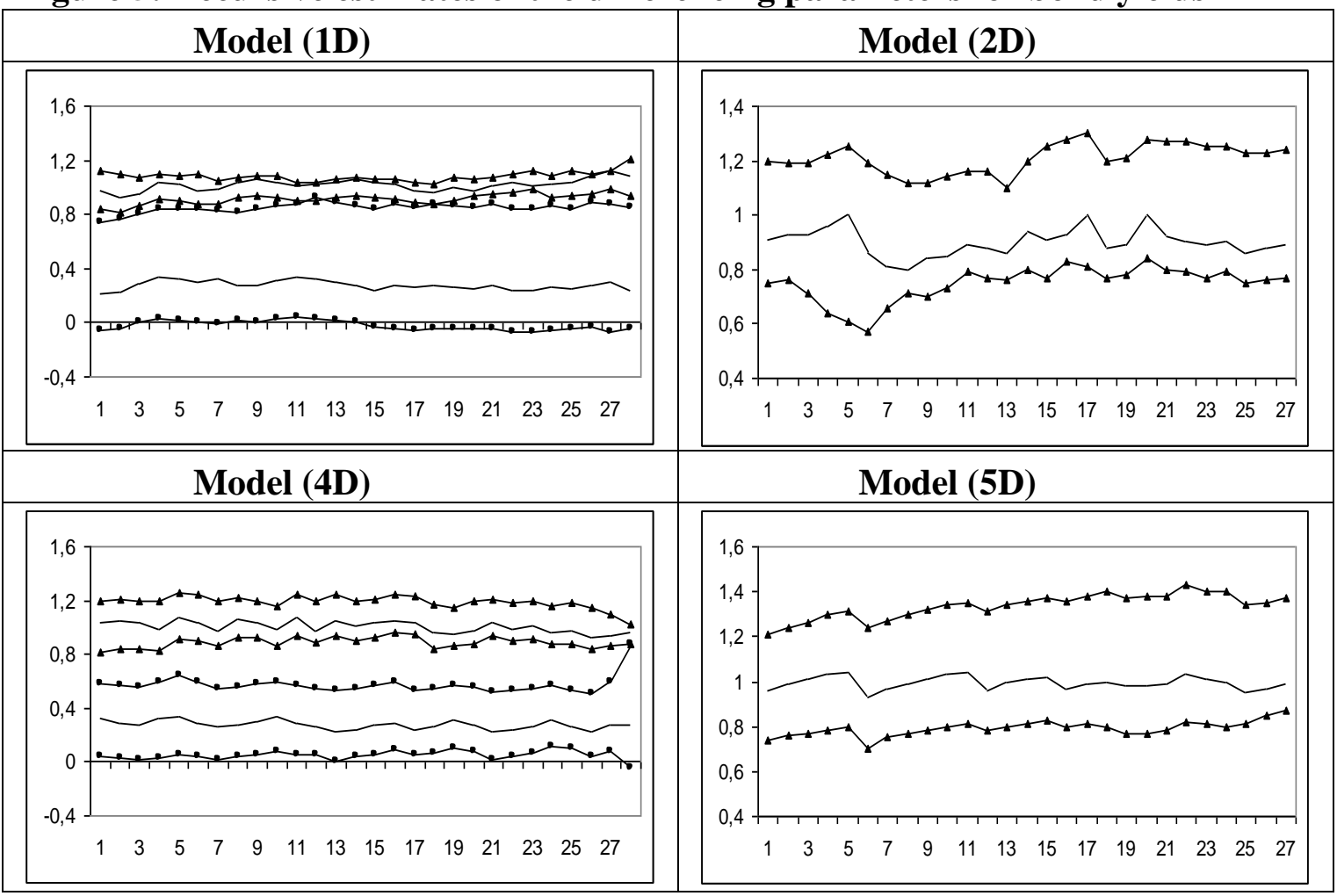

The thin lines refer to the estimates of the fractional differencing parameters, the top one is $\mathrm{d}_{1}$, and the bottom one, $d_{2}$. The $95 \%$ confidence bands are also displayed. 
Figure 6: Recursive estimates of the differencing parameters for stock prices

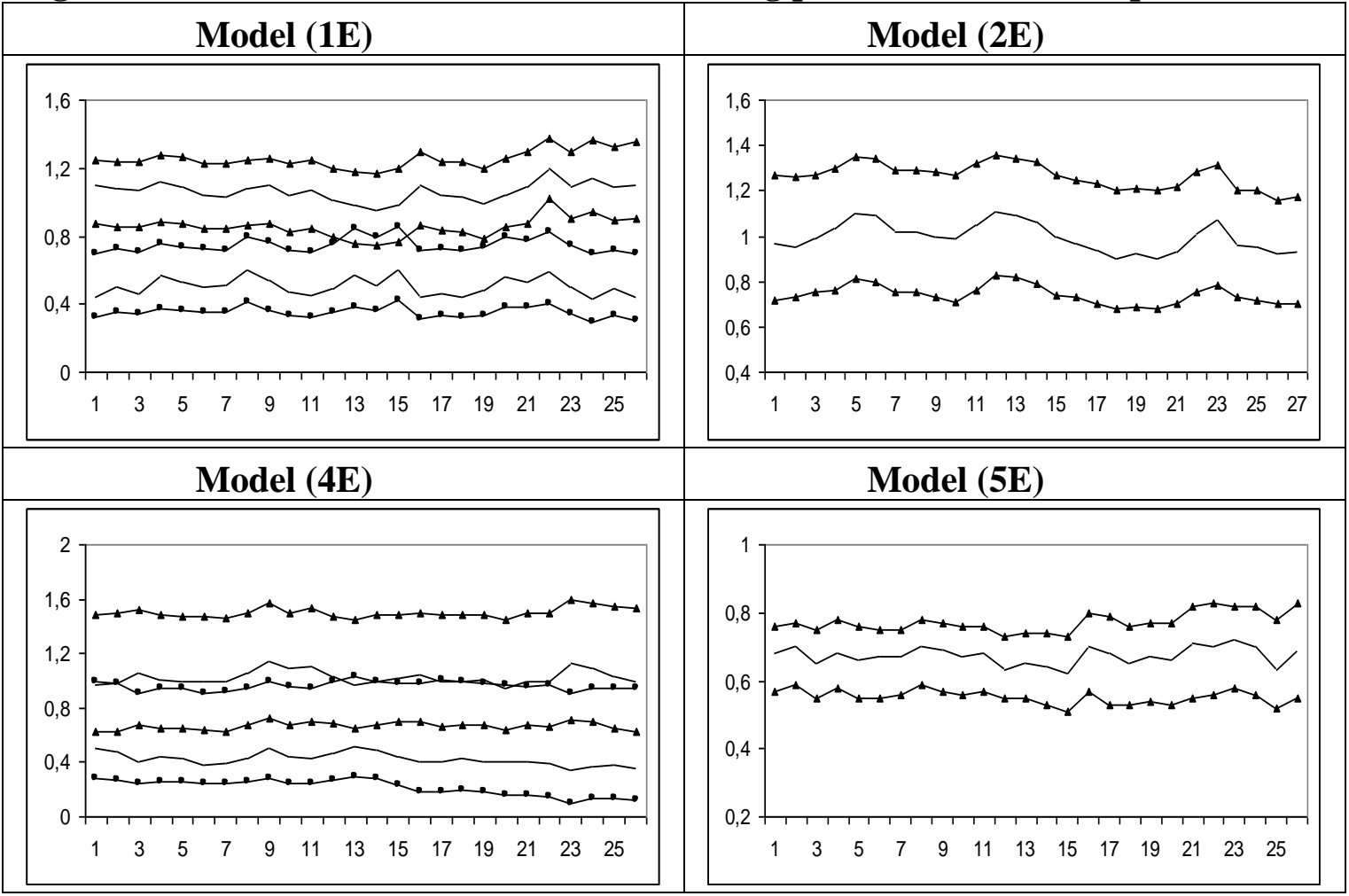

The thin lines refer to the estimates of the fractional differencing parameters, the top one is $\mathrm{d}_{1}$, and the bottom one, $d_{2}$. The $95 \%$ confidence bands are also displayed. 